\title{
¿Puede ejecutarse mediante el establecimiento de la vía de apremio una sanción administrativa recurrida en alzada si el recurso ha sido desestimado por silencio administrativo?
}

\author{
Gregorio Pérez Borrego \\ Abogado
}

\begin{abstract}
SUMARIO: I. LA EJECUTIVIDAD DE LOS ACTOS DE LAS ADMINISTRACIONES PÚBLICAS COMO MANIFESTACIÓN DEL PRIVILEGIO DE AUTOTUTELA EJECUTIVA. EL PROCEDIMIENTO DE APREMIO COMO MODO DE EJECUCIÓN DE LOS ACTOS ADMINISTRATIVOS. II. ¿DESDE QUE MOMENTO PUEDE EJECUTARSE UNA SANCIÓN ADMINISTRATIVA?: EJECUTIVIDAD Y ACTOS DE EJECUCIÓN. UNA PRECISIÓN ¿EN QUÉ MOMENTO ES EJECUTIVA UNA SANCIÓN: CUANDO SE AGOTE LA VÍA ADMINISTRATIVA O CUANDO SEA FIRME EL ACTO ADMINISTRATIVO SANCIONADOR? II.1 ¿Cuándo es ejecutiva una sanción administrativa recurrida en alzada? II.2. La incidencia de la jurisprudencia constitucional en el momento a partir de que son ejecutivas las sanciones administrativas. La importancia de la distinción jurisprudencial entre ejecutividad del acto y realización de actos de ejecución material del mismo. III. DE LA EJECUTIVIDAD DE LA RESOLUCIÓN A LA ACTIVIDAD DE EJECUCIÓN DE LA SANCIÓN ADMINISTRATIVA. IV. EL ESTABLECIMIENTO DE LA VÍA DE APREMIO COMO MEDIO DE EJECUCIÓN DE LAS SANCIONES ADMINISTRATIVAS. V. LA ¿DIFÍCIL? CORRESPONDENCIA DE LOS CONCEPTOS DE LA LRJPAC EN LOS PROCEDIMIENTOS DE EJECUCIÓN DINERARIA DE SANCIONES ADMINISTRATIVAS DE LA LGT. VI. EPÍLOGO
\end{abstract}

I. LA EJECUTIVIDAD DE LOS ACTOS DE LAS ADMINISTRACIONES PÚBLICAS COMO MANIFESTACIÓN DEL PRIVILEGIO DE AUTOTUTELA EJECUTIVA. EL PROCEDIMIENTO DE APREMIO COMO MODO DE EJECUCIÓN DE LOS ACTOS ADMINISTRATIVOS

El artículo 56 de la Ley 30/1992, de 26 de noviembre, del Régimen Jurídico de las Administraciones Públicas y Procedimiento Administrativo Común 
(en adelante LRJPAC) otorga ejecutividad a los actos de las Administraciones Públicas sujetos al Derecho administrativo con arreglo a lo dispuesto en esta Ley, prescripción que conecta con la de su artículo 57.1, que establece la presunción de validez de los actos de las Administraciones Públicas sujetos al Derecho Administrativo, con la lógica consecuencia de producir efectos desde la fecha en que se dicten, salvo que en ellos se disponga otra cosa ${ }^{1}$.

El artículo 94 LRJPAC, titulado "Ejecutoriedad" incide sobre esta cuestión al disponer que "Los actos de las Administraciones Públicas sujetos al Derecho Administrativo serán inmediatamente ejecutivos, salvo lo previsto en los artículos 111 y 138, y en aquellos casos en que una disposición establezca lo contrario o necesiten aprobación o autorización superior"; esto es, a salvo de las previsiones específicas de los supuestos de suspensión del acto en sede administrativa y de los que necesiten de aprobación superior y de las resoluciones dictadas en procedimientos administrativos sancionadores, donde la ejecutividad quedará demorada hasta el agotamiento de la vía administrativa.

Ha declarado la STS (3a, $\left.3^{\text {a }}\right)$ de 7 de mayo de 1999 -recurso de apelación 7805/1991- (RJ 1999, 3936): "El privilegio de ejecutoriedad de los actos administrativos es la cualidad de todo acto administrativo de producir sus normales efectos. El fundamento jurídico de tal privilegio es la presunción de legalidad del acto y la necesidad de que se realicen los intereses públicos”. La jurisprudencia constitucional ha considerado que esa ejecutividad, manifestación de autotutela administrativa, no pugna, en sí misma, con regla o principio alguno de la Constitución (SSTC 238/1992, de 17 de diciembre y 243/2006, de 24 de julio). En términos de la STC 78/1996, de 20 de mayo: «el privilegio de autotutela atribuido a la Administración Pública no es contrario

\footnotetext{
${ }^{1}$ El Consejo de Estado viene utilizando sistemáticamente el siguiente argumento: "Los administrados, en general, y los contribuyentes, en particular, tienen el deber jurídico de soportar la ejecutividad de los actos administrativos (art. 56 de la LRJPAC). La ejecutividad de los actos administrativos, en general, y de las liquidaciones tributarias en particular, tiene su principal fundamento en la presunción de validez de la actuación de las Administraciones Públicas (art. 57.1 de la mencionada Ley). Pero esta presunción general de validez no es 'iuris et de iure': puede desvirtuarse en casos concretos mediante el correspondiente recurso, incluido el contencioso-administrativo. De suerte que, si queda definitivamente establecido que la Administración Tributaria no actuó -en cada supuesto concreto- conforme a Derecho, mientras el particular sí conformó su actuación a lo prevenido en el Ordenamiento Jurídico, caería por su base el deber jurídico de soportar los efectos de la ejecutividad de aquel actuar administrativo contrario a Derecho". Por todos, Dictámenes del Consejo de Estado no 1198/1996 (ECONOMÍA Y HACIENDA), de 27 de junio de 1996, y n⿳o 1096/2001 (HACIENDA), de 24 de mayo de 2001.
} 
a la Constitución, sino que engarza con el principio de eficacia enunciado en el art. 103 de la CE (STC 22/1984), y la ejecutividad de sus actos en términos generales y abstractos tampoco puede estimarse como incompatible con el art. 24.1 de la CE (STC 66/1984 y AATC 458/1988, 930/1988 y 1095/1988)».

El artículo 95 LRJPAC otorga a las Administraciones Públicas, a través de sus órganos competentes en cada caso y previo apercibimiento, el privilegio de ejecutar forzosamente sus actos administrativos, salvo los casos en que suspenda la ejecución de acuerdo con la ley, o cuando la Constitución o la ley exijan la intervención de los Tribunales, y el artículo 96 LRJPPAC como su título indica, regula los medios de ejecución forzosa, a saber: apremio sobre el patrimonio, ejecución subsidiaria, multa coercitiva y compulsión sobre las personas. Como resume el ATC (Sala Primera, Sección Segunda) 930/1988, de 20 de julio: «Sabido es que, en nuestro sistema jurídico, la Administración Pública viene gozando del privilegio de que sus actos sean inmediatamente ejecutivos, de manera que esa ejecutoriedad determina que los actos que dicta obliguen a su inmediato cumplimiento, a la vez que la omisión de ese cumplimiento pueda ser suplido por diversos medios de ejecución forzosa».

La Ley 30/1992, de 26 de noviembre, modula el privilegio de autoejecución por la Administración de sus actos, al establecer en su artículo 96.3 la necesidad de obtener la autorización judicial para la entrada en el domicilio del afectado al fin de ejecutar un acto administrativo en defecto de consentimiento de éste, y respetar el derecho constitucional a la inviolabilidad del domicilio consagrado en el artículo 18.2 de la Norma Suprema², que deberá

\footnotetext{
${ }^{2}$ La STC 139/2004, de 13 de septiembre, realiza un compendio de la jurisprudencia constitucional sobre esta materia, pronunciándose: "En relación con los actos de la Administración cuya ejecución precisa de la entrada en un domicilio, que es el supuesto que ahora interesa, este Tribunal ha señalado que al Juez que otorga la autorización de entrada no le corresponde enjuiciar la legalidad del acto administrativo que pretende ejecutarse. Conviene advertir que esta doctrina, aunque se ha establecido en relación con el Juez de Instrucción, que era quien antes de la reforma efectuada por la Ley 29/1998, de 13 de julio, reguladora de la jurisdicción Contencioso-Administrativa (en adelante LJCA), otorgaba este tipo de autorizaciones, resulta igualmente aplicable a los Jueces de lo contencioso-administrativo, que son los ahora competentes para emitir aquéllas en los casos en los que ello sea necesario para la ejecución de los actos de la Administración pública (art. 8.5 LJCA), pues, en este concreto procedimiento, las atribuciones de estos Jueces se limitan únicamente a garantizar que las entradas domiciliarias se efectúen tras realizar una ponderación previa de los derechos e intereses en conflicto. Como ha señalado este Tribunal (SSTC 160/1991, de 18 de julio, F. 8; 136/2000, de 29 de mayo, F. 3), en estos supuestos la intervención judicial no tiene como finalidad reparar una supuesta lesión de un derecho o interés le-
} 
otorgarse por los Juzgados de lo Contencioso-Administrativo (artículos 91.2 de la Ley Orgánica 6/1985, de 1 de julio, del Poder Judicial y 8.6 de la Ley 29/1998, de 13 de julio, reguladora de la Jurisdicción Contencioso-Administrativa -en adelante LJCA-), cuya intervención contempla asimismo el artículo 8.6 in fine LJCA para acordar la autorización o ratificación judicial de las medidas que las autoridades sanitarias consideren urgentes y necesarias para la salud pública e impliquen privación o restricción de la libertad o de otro derecho fundamental.

Por su parte, el artículo 111 LRJPAC regula el régimen de suspensión de los actos administrativos contra los que se ha interpuesto recurso establecien-

gítimo, como ocurre en otros, sino que constituye una garantía y, como tal, está destinada a prevenir la vulneración del derecho. De ahí que, para que pueda cumplir esta finalidad preventiva que le corresponde, sea preciso que la resolución judicial que autorice la entrada en el domicilio se encuentre debidamente motivada, pues sólo de este modo es posible comprobar, por una parte, si el órgano judicial ha llevado a cabo una adecuada ponderación de los derechos o intereses en conflicto y, por otra, que, en su caso, autoriza la entrada del modo menos restrictivo posible del derecho a la inviolabilidad del domicilio.

Por este motivo, el otorgamiento de esta clase de autorizaciones no puede efectuarse sin llevar a cabo ningún tipo de control, pues si así se hiciera no cumplirían la función de garantizar el derecho a la inviolabilidad del domicilio que constitucionalmente les corresponde. Por esta razón este Tribunal ha sostenido que, en estos supuestos, el Juez debe comprobar, por una parte, que el interesado es el titular del domicilio en el que se autoriza la entrada, que el acto cuya ejecución se pretende tiene una apariencia de legalidad, que la entrada en el domicilio es necesaria para aquélla y que, en su caso, la misma se lleve a cabo de tal modo que no se produzcan más limitaciones al derecho que consagra el art. 18.2 CE que las estrictamente necesarias para la ejecución del acto (SSTC 76/1992, de 14 de mayo, F. 3.a; 50/1995, de 23 de febrero, F. 5; 171/1997, de 14 de octubre, F. 3; 69/1999, de 26 de abril; 136/2000, de 29 de mayo, FF. 3 y 4). Junto a estas exigencias, este Tribunal ha señalado también que han de precisarse los aspectos temporales de la entrada, pues no puede quedar a la discrecionalidad unilateral de la Administración el tiempo de su duración (STC 50/1995, de 23 de febrero, F. 7). Tales cautelas tienen como finalidad asegurar que no se restringe de modo innecesario el derecho a la inviolabilidad del domicilio, evitando un sacrificio desproporcionado de este derecho (SSTC 50/1995, de 23 de febrero, F. 7; 69/1999, de 26 de abril, F. 4). Por ello las exigencias en cada supuesto dependerán de las circunstancias que concurran, pues, como se señala en la STC 69/1999, de 29 de abril, F. 4, los requisitos de detalle formulados a propósito de casos concretos pueden no resultar precisos en otros supuestos en los que las circunstancias sean diferentes.

En definitiva, ha de concluirse que, desde la perspectiva constitucional, la resolución judicial por la que se autoriza la entrada en un domicilio se encontrará debidamente motivada y, consecuentemente, cumplirá la función de garantía de la inviolabilidad del domicilio que le corresponde, si a través de ella puede comprobarse que se ha autorizado la entrada tras efectuar una ponderación de los distintos derechos e intereses que pueden verse afectados y adoptando las cautelas precisas para que la limitación del derecho fundamental que la misma implica se efectúe del modo menos restrictivo posible". 
do que la regla general será la no suspensión, salvo que una disposición establezca lo contrario (artículo 111.1 la LRJPAC), que el órgano competente para resolver el recurso lo acuerdo motivadamente de oficio o a instancia de parte cuando concurran las circunstancias del apartado 2 de este precepto (artículo 111.2 LRJPAC), o en los casos de suspensión automática por transcurso del plazo de treinta días desde que la solicitud tuvo entrada en el registro del órgano competente para decidirla si no ha recaído resolución expresa al respecto (artículo 111.3 LRJPAC).

El artículo 96.1.a) LRJPAC establece como medio de ejecución de los actos administrativos el apremio sobre el patrimonio del deudor, que se completa con el artículo 97.1 LRJPAC, que remite a la aplicación del procedimiento recaudatorio en vía ejecutiva si en virtud de acto administrativo hubiera de satisfacerse cantidad líquida. Ello nos lleva al Reglamento General de Recaudación, aprobado por Real Decreto 939/2005, de 29 de julio (en adelante RGR), cuyo preámbulo ya anuncia, que tiene, desde el punto de vista material, un ámbito de aplicación más amplio que el contenido en la Ley 58/2003, de 17 de diciembre, General Tributaria (en adelante LGT), puesto que no se circunscribe al cobro de las deudas y sanciones tributarias, sino también al de los demás recursos de naturaleza pública. Así, el artículo 1.1 del RGR, al establecer su Ámbito de aplicación, determina que "este Reglamento regula la gestión recaudatoria de los recursos de naturaleza pública en desarrollo de la Ley 58/2003, de 17 de diciembre, General Tributaria, de la Ley 47/2003, de 26 de noviembre, General Presupuestaria, y de las demás leyes que establezcan aquéllos"; y el artículo 2 del RGR, al definir el concepto de gestión recaudatoria de la Hacienda Pública, dispone que ésta consiste en "el ejercicio de la función administrativa conducente al cobro de las deudas y sanciones tributarias y demás recursos de naturaleza pública que deban satisfacer los obligados al pago", precisando en su párrafo segundo que "A efectos de este Reglamento, todos los créditos de naturaleza pública a que se refiere este artículo se denominarán deudas". El artículo 2.3 del RGR contiene una norma de remisión expresa a la Ley General Tributaria al establecer que "El cobro en período ejecutivo de los recursos a los que se refiere el párrafo anterior se efectuará por el procedimiento de apremio regulado en la Ley 58/2003, de 17 de diciembre, General Tributaria, y en este Reglamento".

Son varias las cuestiones que se plantean: primera, desde qué momento es ejecutivo un determinado tipo de acto administrativo: las resoluciones sancionadoras; segunda, a partir de qué momento esta ejecutividad permite desarrollar la actividad administrativa de ejecución de estos actos y tercera, cómo se conjuga un proceso de ejecución administrativa como el de apremio, de na- 
turaleza eminentemente tributaria, cuando la Disposición Adicional quinta LRJPAC remite a los procedimientos administrativos en materia tributaria a su regulación específica y, en su defecto y con carácter supletorio, a las disposiciones de la Ley 30/1992, de 26 de noviembre.

\section{II. ¿DESDE QUÉ MOMENTO PUEDE EJECUTARSE UNA SANCIÓN ADMINISTRATIVA?: EJECUTIVIDAD Y ACTOS DE EJECUCIÓN. UNA PRECISIÓN ¿EN QUÉ MOMENTO ES EJECUTIVA UNA SANCIÓN: GUANDO SE AGOTE LA VÍA ADMINISTRATIVA O CUANDO SEA FIRME EL ACTO ADMINISTRATIVO SANCIO- NADOR?}

La jurisprudencia ha observado: "Debe diferenciarse, tratándose de resoluciones administrativas, entre ejecutividad y actividad de ejecución. Lo primero expresa una calidad de dicha resolución, consistente en la posibilidad que permite de ser llevada a la práctica mediante actos materiales de ejecución. Mientras que lo segundo son esos propios actos materiales por los que se lleva a la práctica la resolución, y que son algo distinto de esta última, aunque arranquen de ella" ${ }^{3}$. Se distinguen así dos momentos: uno, desde que el acto administrativo es ejecutivo y por tanto ejecutable y, otro, cuando la Administración comienza las actuaciones materiales para asegurar su cumplimiento si éste no se ha realizado de manera voluntaria por el destinatario del mismo, mediante los trámites del procedimiento de ejecución administrativa.

Aplicando esta doctrina a las sanciones administrativas debemos distinguir dos momentos, aquel en el que éstas serán ejecutivas, lo que por disposición de los artículos 94 y 138.1 LRJPAC, se conseguirá una vez pongan fin a la vía administrativa; y aquel otro, a partir del cual podrá la Administración iniciar acciones materiales para la ejecución de éstas mediante los medios que le otorga el artículo 96 LRJPAC, y entre ellos, el establecimiento del procedimiento de apremio.

3 SSTS (3무 $7^{\text {a }}$ ), de 12 noviembre 1999 -recurso de casación núm. 8267/1995- (RJ 1999, 10050), de 2 enero 2001 -recurso de casación núm. 6792/1996- (RJ 2001, 1144), de 16 de enero de 2001 -recurso de casación núm. 7134/1996- (RJ 2001, 4413), de 17 julio 2001 -recurso de casación núm. 503/1997- (RJ 2001, 6916), de 11 octubre 2002 -recurso de casación núm. 7376/1998- (RJ 2002, 10220), de 14 noviembre 2002 -recurso de casación núm. 8966/1998- (RJ 2002, 9925), de 5 octubre 2004 -recurso de casación núm. 6633/2000- (RJ 2004, 6299), y de 24 noviembre 2004 -recurso de casación núm. 3071/2001- (RJ 2004, 8173). 
Respecto del primero de los momentos señalados -el que señala la ejecutividad de la sanción-, es importante destacar la utilización de la expresión legislativa «fin a la vía administrativa», en vez de acudir al criterio de la «firmeza» (entiéndase firmeza administrativa) ${ }^{4}$ de la sanción como presupuesto de su ejecutividad. Ello porque una interpretación literal del precepto determinaría que los actos que pondrían fin a la vía administrativa serían exclusivamente los enumerados en el artículo 109 LRJPAC, con lo que las resoluciones sancionadoras susceptibles de ser recurridas en vía administrativa, pero respecto de las cuales se ha dejado transcurrir el plazo para su interposición, habrían ganado firmeza, aunque no pondrían fin a la vía administrativa y no tendrían la consideración de ejecutivas.

La jurisprudencia ha optado por una interpretación más teleológica que literal y ha acogido el criterio de la firmeza como presupuesto para la ejecutividad de la sanción, perfilando los contornos de esta institución. Así, la STC 243/2006, de 24 de julio, hace constantes referencias a la firmeza del acto administrativo como presupuesto necesario para la ejecución de la sanción. La STS (3ª $7^{\underline{a}}$ ) de 20 abril 2004 -recurso de casación núm. 1056/1998- (RJ 2004, 3324), declara: "(es) obvio es que el importe de la sanción no podía ser ejecutado por la Administración en el plazo en que la sanción no era susceptible de ser reclamada o ejecutada hasta alcanzar firmeza en la vía administrativa [...]”. La STS $\left(3^{\underline{a}}, 4^{\underline{a}}\right)$ de 4 de julio de 2005 -recurso de casación núm. 6951/2003- (RJ 2005, 5200), confirmando la STSJ de Navarra de 13 de junio de 2003, declara: "En el caso de las resoluciones sancionadoras la ejecutividad del acto está condicionada a su firmeza en vía administrativa según el artículo 138.3 de la Ley citada", y la STS $\left(3^{\underline{a}}, 6^{\mathrm{a}}\right)$ de 24 de octubre de 2000 -recurso de casación núm. 4553/1996- (RJ 2000, 9375), acoge el criterio de la firmeza de la resolución sancionadora como presupuesto de su ejecutividad, determinando el alcance de esta firmeza, afirmando: "por efecto del principio de autotutela administrativa, basta que el acto sancionador haya adquirido firmeza en vía administrativa para que sea ejecutivo, aun cuando pueda hallarse pendiente un recurso contencioso-administrativo en el que no se haya acordado una medida cautelar de suspensión de los efectos del acto sancionador (artículo 138.3 LRJPAC). Por otra parte, la Ley de Régimen Jurídico de las Administraciones Públicas y del Procedimiento Administrativo Común emplea la expresión «firme» refiriéndose preferentemente, cuando de una resolución administrativa se trata, a la imposibilidad de interponer contra ella recursos

\footnotetext{
${ }^{4}$ SAEZ HIDALGO, Ignacio: "Efectos del silencio administrativo en vía de recurso: la prescripción de sanciones”. Actualidad Jurídica Aranzadi núm. 402, Agosto, 1999, pgs. 1 -5.
} 
administrativos ordinarios y, por ende, contemplando sólo la firmeza en vía administrativa y no la firmeza en vía jurisdiccional (v. gr., artículos 102.4, 108, 115.1.III y 118.1) y sólo en algún caso resulta dudoso este sentido de la expresión (v. gr., art. 132.3)". La Sentencia del Pleno de la Sala Tercera del Tribunal Supremo de 7 de marzo de 2005 -recurso de casación núm. 715/1999, con varios votos particulares, trata de zanjar la cuestión, pronunciándose: "lo que se exige para la ejecutividad de la sanción es la llamada firmeza en vía administrativa (o sea, que ésta se agote) y no la firmeza en el sentido de que, hasta la resolución del oportuno recurso jurisdiccional, en el supuesto de que fuera desestimado, no podría afirmarse que la sanción había quedado firme en vía administrativa" 5 .

En definitiva, aunque los términos de la Ley aludan al fin de la vía administrativa para la ejecutividad de las resoluciones sancionadoras, en atención a los argumentos expuestos, cabe interpretar esta expresión como firmeza de la resolución, como criterio admitido por la jurisprudencia para que la sanción administrativa sea ejecutiva.

\section{II.1) ¿CUÁNDO ES EJECUTIVA UNA SANCIÓN ADMINISTRATIVA RECU- RRIDA EN ALZADA?}

Ha observado el Consejo de Estado: "la suspensión de la eficacia de los actos administrativos no tiene siempre el mismo significado y alcance. Parece justificado distinguir el régimen general de suspensión de aquel que debe regir cuando el acto recurrido es consecuencia del ejercicio de la potestad sancionadora de la Administración [...]. Por ello, [...] aunque la Constitución atri-

\footnotetext{
${ }^{5}$ Los tres votos particulares emitidos a esta Sentencia del Pleno de la Sala Tercera del Tribunal Supremo coinciden con el sentir mayoritario de la Sala en esta tesis, afectando las discrepancias si la firmeza se alcanza una vez agotada la vía administrativa o habrá que esperar a la resolución definitiva en sede jurisdiccional. Así, el voto particular del Magistrado D. Ricardo Enríquez Sancho afirma: "No parece dudoso que la expresión 'hasta que sean firmes en vía administrativa' equivale a hasta que los actos hayan causado estado en vía administrativa". Por su parte, el voto particular del Magistrado D. Manuel Campos Sánchez-Bordona, se pronuncia: "Es cierto -y en ello coincido con el voto mayoritario- que el significado usual en nuestro ordenamiento de la expresión 'firmeza en vía administrativa' coincide con el agotamiento de esta vía: es firme en ella la resolución que de modo definitivo y sin posibilidad de ulterior recurso o reclamación de orden administrativo resulta ya inobjetable dentro de los propios cauces administrativos (a salvo de los supuestos excepcionales del recurso de revisión) [...] firmeza en vía administrativa equivale a agotamiento de los recursos o reclamaciones específicamente administrativos, a 'causar estado' en dicha vía”. El voto del Magistrado D. Manuel Vicente Garzón Herrero afirma: "el término 'firmeza administrativa' tiene un sentido propio. Un acto administrativo es firme cuando contra el no cabe recurso ordinario alguno, ya sea administrativo o jurisdiccional".
} 
buye al legislador una cierta libertad de configuración, dentro de los postulados constitucionales, sobre el régimen de suspensión de los actos (también de los sancionadores) cuando son objeto de recurso, pudiera ser conveniente y más conforme con las garantías del ciudadano establecer (aquí o al tratar de la potestad sancionadora) la regla general de suspensión de la ejecutividad respecto de las sanciones de protección del orden general"”.

Acogiendo esta doctrina, la Ley 30/1992, de 26 de noviembre, distingue un régimen diferenciado de ejecutividad para las sanciones administrativas al establecer en su artículo 138.3 para los actos dictados en procedimientos administrativos sancionadores que «La resolución será ejecutiva cuando ponga fin a la vía administrativa". Posiblemente esta solución dada por el legislador sea la más acorde con los diversos principios que recoge la propia Ley 30/1992, de 26 de noviembre, de manera que ninguno per se desvirtúe totalmente a otro (con las precisiones que realizamos en apartados anteriores sobre su terminología). Así, la presunción de legalidad genérica de los actos administrativos es un privilegio que entra en tensión con la presunción de inocencia aunque la jurisprudencia constitucional ha declarado que no vulnera la tutela judicial efectiva «la ejecutividad de las sanciones impuestas en aplicación de la propia Ley, una vez sean firmes en vía administrativa» ${ }^{7}$. En definitiva, en la norma general contenida en la Ley 30/1992, la ejecutividad del acto o resolución que impone una sanción se demora hasta su firmeza administrativa, si bien cabe entender incluso que hasta su confirmación por los Tribunales ${ }^{8}$. En términos de la STC 243/2006, de 24 de julio: «la Ley de régimen jurídico de las Administraciones públicas y del procedimiento administrativo común no excepciona a las sanciones administrativas de la regla de la ejecutividad, si bien exige que la resolución correspondiente ponga fin a la vía admi-

\footnotetext{
${ }^{6}$ Dictamen del Consejo de Estado no 1076/1991, de 30 de octubre de 1991, sobre el Anteproyecto de Ley de Régimen Jurídico de las Administraciones Públicas.

${ }^{7}$ STC 341/1993 citada en la STC 78/1996, de 20 de mayo.

${ }^{8}$ Informe del Consejo General del Poder Judicial de 26 de julio de 2000, al anteproyecto de Ley Orgánica de reforma de la Ley Orgánica 4/2000, de 11 de enero, sobre derechos y libertades de los extranjeros en España y su integración social, p. 31. No obstante, esta tesis, que se alinea con la de los votos particulares a la Sentencia del Pleno de la Sala Tercera del Tribunal Supremo de de 7 de marzo de 2005 -recurso de casación núm. 715/1999- es contraria al sentido de ésta de considerar que las sanciones administrativas son ejecutivas una vez adquieran firmeza en vía administrativa sin esperar su firmeza en sede jurisdiccional, a salvo de lo que pudiera decidir sobre su posibles suspensión el Tribunal que conociera del recurso contra la misma.
} 
nistrativa (art. 138.3 LPC)». No obstante, esta afirmación debe matizarse, como veremos en apartados posteriores.

El artículo 109.1.a) LRJPAC dispone que ponen fin a la vía administrativa las resoluciones de los recursos de alzada, de lo que se deduce, aunque resulte obvio, que no pondrán fin a la vía administrativa las resoluciones sancionadoras que, siendo susceptibles de ello, hayan sido recurridas en alzada. Ahora bien, una vez interpuesto el recurso de alzada contra la sanción caben dos posibilidades: que el órgano jerárquicamente superior al que dictó la resolución sancionadora resuelva expresamente el recurso o que éste incumpla su deber de resolver expresamente dejando transcurrir el plazo para que el interesado pueda considerarlo desestimado por silencio administrativo.

Si la Administración cumple con su obligación de resolver expresamente será la resolución del recurso de alzada la que ponga fin a la vía administrativa, ahora bien, ¿qué ocurre si el órgano competente para resolver el recurso de alzada interpuesto contra la resolución sancionadora no actúa, dejando transcurrir el plazo de tres meses para considerarlo desestimado por silencio administrativo previsto en el artículo 115.2 LRJPAC? En otras palabras ¿pone fin a la vía administrativa y por tanto permite la ejecución del acto sancionador la desestimación presunta por silencio de un recurso de alzada interpuesto contra una resolución sancionadora?

Observa la Dirección General del Servicio Jurídico del Estado en su Dictamen de 25 de septiembre de $2001^{9}$, diferenciando este supuesto del que se produce si el recurso pendiente de resolución es el potestativo de reposición, que existen tres criterios posibles: llevar a cabo de inmediato, una vez se produce el silencio negativo, la ejecución de la sanción; aguardar a que transcurra el plazo de seis meses que prevé el artículo 46.1 de la LJCA para interponer un recurso contra una desestimación presunta; o por último, aguardar a que se produzca la resolución expresa del recurso, en tanto para la Administración persiste la obligación de resolver aunque se haya producido el acto presunto.

Estas tres posibilidades pueden reducirse a dos, dado que la segunda no es sino la primera con matices, quedando la cuestión ceñida a si los actos ad-

\footnotetext{
${ }^{9}$ Dictamen de la Dirección General del Servicio Jurídico del Estado de 25 de septiembre de 2001 (ref: A.G. Medio Ambiente 2/01). Ponente: don Luciano J. Mas Villarroel, sobre "Ejecutividad de resoluciones sancionadoras que hubieran sido recurridas en vía administrativa y desestimados por silencio administrativo los recursos interpuestos".
} 
ministrativos de carácter sancionador que han sido recurridos en alzada son ejecutivos desde que se produce la desestimación por silencio (haya transcurrido o no el plazo de interposición del recurso contencioso-administrativo contra esa desestimación presunta por el transcurso de los seis meses previstos en el artículo 46.1 de la LJCA), o si por el contrario, es necesario que el recurso de alzada se haya desestimado total o parcialmente de manera expresa mediante resolución dictada por el órgano competente y debidamente notificada al interesado. En definitiva, ¿determina el transcurso del plazo de tres meses sin haber recaído resolución expresa del recurso de alzada contra la sanción, o lo que es lo mismo su desestimación por silencio, la firmeza de la resolución administrativa sancionadora o, para que ésta se produzca es necesaria la desestimación expresa del recurso?

Considera el Consejo de Estado que: "El silencio negativo no produce un acto administrativo presunto, sino sólo una ficción, a efectos de facilitar al administrado la impugnabilidad del acto [...] (e) implica sólo una ficción con efectos puramente procesales que permite al interesado acceder a la tutela judicial y no impide a la Administración, transcurrido el plazo, resolver en cualquier sentido" 10 . Como ha declarado la STS $\left(3^{\underline{a}}, 2^{\underline{a}}\right)$ de 2 de octubre de 1997 -recurso 675/1993- (RJ 1997, 7742), dictada en el procedimiento de impugnación directa del Real Decreto 803/1993, de 28 mayo, en el que se modifican determinados procedimientos tributarios: «Esta Sala se ha pronunciado en muchas ocasiones sobre la naturaleza y efectos del silencio administrativo negativo y sus consecuencias procedimentales en relación a la tutela judicial efectiva. Así en la Sentencia de 18 marzo 1995 (RJ 1995, 2501) se dice que del hecho de que la Administración vulnere el ordenamiento jurídico infringiendo su deber de resolver expresamente las peticiones y recursos de parte, ningún menoscabo puede derivarse para el derecho a la tutela judicial efectiva del administrado, ya que, en definitiva, al ser el acto denegatorio presunto por silencio una ficción legal introducida en beneficio del administrado y no existir, por tanto, acto administrativo propiamente dicho, no puede aplicarse al mismo la calificación de consentido, por razón del tiempo transcurrido y de definitivamente inimpugnable; sin olvidar, tampoco, que no es razonable primar la inactividad de la Administración, colocándola en mejor situación que si hubiera resuelto y notificado la resolución reglamentariamente.

${ }^{10}$ Dictamen del Consejo de Estado no 5356/1997, de 22 de enero de 1998, sobre el Anteproyecto de Ley de Modificación de la Ley 30/1992, de 26 de noviembre, de Régimen Jurídico de las Administraciones Públicas y del Procedimiento Administrativo Común. 
Más recientemente la Sentencia de 28 octubre 1996 (RJ 1996, 9582), ha recordado una reiterada doctrina de esta Sala que ha venido a establecer que el silencio no es una opción para que la Administración pueda elegir entre resolver expresamente o no hacerlo, sino una garantía para los administrados frente a la pasividad de los Órganos obligados a resolver, garantía de la que se puede hacer uso o esperar a la resolución expresa sin que ello pueda comportar en principio ningún perjuicio al interesado. Por otra parte, dice también la sentencia citada, el silencio tampoco es un acto administrativo sino una ficción jurídica que deviene innecesaria cuando se produce, aunque sea con retraso, la resolución expresa, reabriéndose con ella el plazo para el recurso jurisdiccional, que no cerró la prolongación del precedente silencio de la Administración.

Dando un paso más la expresada sentencia llega a decir «pero es que, además, a la expresa resolución desestimatoria debidamente notificada, aunque sea de forma tardía, ha de equipararse cualquier actuación de la Administración incursa en la mora tendente a ejecutar el acto recurrido, con lo que la presunción desestimatoria se confirma. Doctrina de esta Sala que se apoya expresamente en la STC 6/1986, de 21 enero y que puede delimitarse diciendo que ante la falta de resolución expresa de la Administración, en el caso de silencio negativo, el interesado puede optar por tener por denegada su pretensión y ejercitar los recursos pertinentes en los plazos legalmente establecidos, contados desde que se presume producida la denegación, o bien, esperar a que la Administración se pronuncie, ya lo haga cumpliendo sus obligaciones y resolviendo expresamente, aunque lo sea con retraso, o simplemente vuelva a confirmar tácitamente aquella primera denegación presunta, intentando ejecutar, incluso de manera simplemente fáctica, al acuerdo ficticiamente adoptado, abriéndose de nuevo, en ambos casos, todos los plazos para su impugnación.

Queda pues claro que cualquier norma reglamentaria que obligara a tener por desestimadas las peticiones de los administrados una vez transcurridos los plazos de resolución, sin darles oportunidad de optar por esperar a la resolución expresa, sería contraria al ordenamiento jurídico y violaría el principio constitucional que proscribe la indefensión».

Esta jurisprudencia aclara no sólo la naturaleza de ficción jurídica del silencio administrativo a efectos procesales para posibilitar el acceso a la jurisdicción de los interesados, sino también otra cuestión conexa: la reapertura de los plazos procesales para la impugnación del acto desestimado por silencio administrativo en casos de la actuación administrativa que confirma tácita- 
mente la denegación presunta, al tratar de ejecutar, incluso de manera simplemente fáctica, el acuerdo ficticiamente adoptado. Ello nos da un argumento adicional a los utilizados por la Dirección del Servicio Jurídico del Estado en su Dictamen de 25 de septiembre de 2001, para rechazar la posibilidad de ejecutar las sanciones administrativas recurridas en alzada y desestimado el recurso por silencio administrativo una vez transcurrido el plazo de seis meses para la interposición del recurso contencioso-administrativo previsto en el artículo 46.1 de la LJCA, dado que el hecho de que el administrado no haya recurrido ante la jurisdicción contencioso-administrativa el acto sancionador contra el que se interpuso recurso de alzada desestimado por silencio en el plazo de seis meses dado por el artículo 46.1 in fine de la LJCA no cierra definitivamente la vía jurisdiccional como declara la jurisprudencia referida. Los argumentos en contra de esta tesis no acaban ahí puesto que la STC 243/2006, de 24 de julio, aporta más, que trataremos infra.

La STC 220/2003, de 15 de diciembre, reiterando su doctrina y citando expresamente la STC 188/2003, aporta otra razón para rechazar la esta postura, afirmando: «[si] el silencio negativo es una institución creada para evitar los efectos paralizantes de la inactividad administrativa, es evidente que ante una resolución presunta de esta naturaleza el ciudadano no puede estar obligado a recurrir, siempre y en todo caso, so pretexto de convertir su inactividad en consentimiento con el acto presunto, exigiéndosele un deber de diligencia que no le es exigido a la Administración. Deducir de ese comportamiento pasivo -que no olvidemos, viene derivado de la propia actitud de la Administración- un consentimiento con el contenido de un acto administrativo que fue impugnado en tiempo y forma, supone una interpretación absolutamente irrazonable desde el punto de vista del derecho de acceso a la jurisdicción, como contenido esencial del derecho a la tutela judicial efectiva previsto en el art. 24.1 CE, pues no debemos descuidar que la Ley no obliga al ciudadano a recurrir un acto presunto y sí a la Administración a resolver, de forma expresa, el recurso presentado» (F. 6).

La jurisprudencia constitucional ha interpretado la institución del silencio administrativo desde otra perspectiva: la del derecho fundamental a la tutela judicial efectiva, que comprende el derecho a promover la actividad jurisdiccional y obtener una resolución fundada en Derecho, y de la institución del silencio administrativo como requisito de acceso a la jurisdicción, que enlaza con el control de la actividad administrativa que compete a los tribunales por juego de los artículos 106.1 de la Constitución y 8 de la Ley Orgánica 6/1985, de 1 de julio, del Poder Judicial. La citada STC 220/2003, de 15 de diciembre, sostiene: «la Administración no puede verse beneficiada por el incumpli- 
miento de su obligación de resolver expresamente en plazo solicitudes de los ciudadanos, pues este deber entronca con la cláusula del Estado de Derecho (art. 1.1 CE), así como con los valores que proclaman los arts. 24.1, 103.1 y 106.1 CE (por todas, SSTC 6/1986, de 21 de enero, F. 3; 204/1987, de 21 de diciembre, F. 4; 180/1991, de 23 de septiembre, F. 1; 86/1998, de 21 de abril, FF. 5 y 6 ; 71/2001, de 26 de marzo, F. 4; y 188/2003, de 27 de octubre, F. 6). Por este motivo, hemos dicho también que el silencio administrativo de carácter negativo se configura como "una ficción legal que responde a la finalidad de que el administrado pueda, previos los recursos pertinentes, llegar a la vía judicial superando los efectos de inactividad de la Administración», de manera que, en estos casos, no puede calificarse de razonable aquella interpretación de los preceptos legales «que prima la inactividad de la Administración, colocándola en mejor situación que si hubiera cumplido su deber de resolver" [SSTC 6/1986, de 21 de enero, F. 3 c); 204/1987, de 21 de diciembre, F. 4; 180/1991, de 23 de septiembre, F. 1; 294/1994, de 7 de noviembre, F. 4; 3/2001, de 15 de enero, F. 7; y 179/2003, de 13 de octubre, F. 4] [...] Pues el incumplimiento [...] de su obligación legal de resolver de forma expresa el recurso de reposición interpuesto (arts. 94.3 LPA/1958 y 42 LRJPAC), de un lado, y de la obligación de comunicar -precisamente por esa falta de respuesta administrativa- la necesaria instrucción de recursos (arts. 79.2 LPA/1958 y 58.2 LRJPAC), de otro lado, "ha supuesto que la Administración se beneficiara de su propia irregularidad", por lo que, como este Tribunal ha manifestado reiteradamente, "no puede calificarse de razonable una interpretación que prime los defectos en la actuación de la Administración, colocándola en mejor situación que si hubiera cumplido su deber de notificar con todos los requisitos legales" (por todas, STC 179/2003, de 13 de octubre, F. 4) ${ }^{11}$. Y no desdice la anterior conclusión el hecho de que la Administración demandada hubiese tenido la cautela de incluir en la liquidación impugnada no sólo los recursos pertinentes contra la propia liquidación — recurso de reposición- sino incluso también contra su eventual desestimación presunta - recurso contencioso-administrativo-, pues la citada instrucción de recursos de un acto administrativo no excusaba a la Administración de su obligación legal de resolver el recurso interpuesto, comunicando al interesado "la indicación de si es o no definitivo en la vía administrativa y, en su caso, la expresión de los recursos que contra el mismo procedan, órgano ante el que hubieran de presentarse y plazo para interponerlos" (art. 79.2 LPA/1958, hoy 58.2 LRJPAC). Es absolutamente inaceptable que una Administración pública que debe ac-

${ }^{11}$ Doctrina que se reitera en resoluciones posteriores como las SSTC 73/2005, de 4 de abril y 243/2006, de 24 de julio. 
tuar "con sometimiento pleno a la ley y al Derecho" (art. 103.1 CE), desatienda, primero, el cumplimiento de sus obligaciones para con los ciudadanos y, sin embargo, manifieste luego un extremado celo en la exigencia de éstos, pues ninguna pretendida eficacia administrativa puede justificar el desconocimiento de uno de los valores superiores de nuestro ordenamiento jurídico: el valor justicia (art. 1.1 CE). Por este motivo, no es posible entender que la resolución desestimatoria presunta de un recurso de reposición, por silencio administrativo de carácter negativo, reúne, en modo alguno, los requisitos formales de que se debe revestir todo acto administrativo, por el simple hecho de que el acto impugnado sobre el que pende la inactividad administrativa incluyó una detallada instrucción de recursos, presentes y futuros».

Una visión crítica del silencio administrativo en base a un argumento que aunque no ha sido utilizado ni por la legislación ni por la jurisprudencia española bien pudiera haberlo sido: no cumplir con la exigencia de motivación de las resoluciones denegatorias sobre determinadas materias, la encontramos en la STJCE Luxemburgo (Sala Segunda) de 21 de abril de 2005 Housieaux. Cuestión Prejudicial. Asunto C-186/2004, que considera ilegal la resolución denegatoria presunta por silencio en materia de derecho de acceso a la información en materia de medio ambiente de la Directiva 90/313/CEE, expresándose en los siguientes términos: «34. Contrariamente a la normativa nacional que fue objeto de la sentencia Comisión/Francia, antes citada, según la cual se considera que el silencio mantenido por la autoridad pública durante un período de un mes respecto a la solicitud de información constituye una decisión denegatoria presunta de dicha solicitud, la normativa controvertida en el litigio principal prevé que se produce una decisión denegatoria presunta tras guardar silencio los dos meses siguientes a la presentación de la solicitud. 35. Por tanto, de la sentencia Comisión/Francia, antes citada, resulta que si la Directiva 90/313 no se opone, a efectos de la concesión de una tutela judicial efectiva de conformidad con el artículo 4 de la citada Directiva, a la ficción de una decisión denegatoria presunta de una solicitud de acceso a la información tras un silencio de dos meses, el artículo 3, apartado 4, de la mencionada Directiva se opone a que tal decisión no contenga una motivación en el momento de la expiración del plazo de dos meses. En estas circunstancias, la decisión denegatoria presunta constituye ciertamente una "respuesta" en el sentido de esta disposición pero debe considerarse ilegal».

Estas consideraciones podrían ser aplicables en nuestro ordenamiento, dado que incluso asumiendo que el silencio administrativo negativo no vulnera la tutela judicial efectiva del administrado al considerarse una ficción jurídica que permite entender desestimada la pretensión y abre la posibilidad de 
acceder a la jurisdicción, resulta obvio que al no existir acto no puede existir motivación, que es una obligación que la Ley exige a la Administración en los actos limitativos de derechos (artículo 54.1.a LRJPAC) entre los que se encuentran los sancionadores como recoge expresamente el artículo 138.1 LRJPAC, y si bien es cierto que la resolución del recurso de alzada contra el acto que impone la sanción no es la resolución sancionadora propiamente dicha ${ }^{12}$, no lo es menos que será el acto administrativo que lo confirme o revoque, por lo que deberá ser igualmente motivado, siquiera por remisión a la motivación del acto recurrido.

${ }^{12}$ Sobre la extensión del procedimiento administrativo sancionador se ha pronunciado la STS $\left(3^{\underline{a}}, 5^{\mathrm{a}}\right)$ de 30 de noviembre de 2004 -recurso de casación en interés de Ley no $97 / 2002-(\mathrm{RJ} 2005$, 4800 ), que al haber sido estimado, su doctrina vincula a todos los tribunales inferiores por disposición del artículo 100.7 de la Ley 29/1998, de 13 de julio, de la Jurisdicción Contencioso-Administrativa, pronuncia: «NOVENO El ejercicio de la potestad sancionadora -y, en consecuencia, la prescripción de la misma derivada de la inacción o paralización administrativa- sólo se produce en el ámbito del procedimiento establecido, materializado en un expediente sancionador, y que concluye con la resolución sancionadora y su consiguiente notificación. Con tal determinación concluye el ejercicio de la potestad sancionadora para la que la Administración se encuentra legalmente habilitada, debiendo la misma desarrollarse, con arreglo a unos determinados principios y garantías, y en un período de tiempo determinado cuyo incumplimiento puede dar lugar a la caducidad del procedimiento o a la prescripción de las infracciones perseguidas.

Por ello no resulta trasladable a la posterior vía de recurso, cuando el ejercicio de la potestad sancionadora ya ha concluido y se ha consumado, los parámetros temporales que en la vía sancionadora hubieran determinado la prescripción de la infracción. En la posterior vía de recurso se ejercita por la Administración una potestad administrativa diferente, cual es la relativa a la revisión de la previa actuación administrativa y que se orienta no a persecución de la infracción -propio de la potestad sancionadora- sino a la comprobación de si el órgano inferior se ajustó -formal y materialmente- al ordenamiento jurídico en el ejercicio -entonces, sí- de la potestad sancionadora.

Por ello, el ámbito propio de la prescripción es el del expediente sancionador que finaliza, culmina y se acaba con la resolución (y consiguiente notificación) sancionadora (de resultar la misma procedente), momento en el que se agota por parte de la Administración actuante el ejercicio de la potestad sancionadora. En consecuencia, la demora en la resolución expresa del recurso administrativo -al margen de la posible exigencia de responsabilidades- sólo da lugar al silencio administrativo negativo o desestimatorio que habilita y permite la posterior revisión jurisdiccional, de conformidad con el artículo 115.2 de la LRJPAC, en relación con el actual 43.2 in fine, que, a diferencia del antiguo (antes de la Ley 4/1999) 43.3.b, que se refería a los «recursos administrativos", ahora menciona, para excluirlos del silencio positivo, a los "procedimientos de impugnación de actos y disposiciones». No cabe, pues, duda acerca de la distinta naturaleza y finalidad de ambos procedimientos (sancionador y de impugnación de actos y disposiciones), y de la diferente potestad administrativa que en cada uno de ellos se ejercita». 
La Dirección del Servicio Jurídico del Estado, en su Dictamen de 25 de septiembre de $2001^{13}$ considera que la vía administrativa en los procedimientos sancionadores en los que cabe interponer recurso de alzada contra el acto que impone la sanción sólo se agota cuando recae resolución expresa de éste. Ello, porque aunque el artículo 109.a) LRJPAC no establece distinción entre resoluciones expresas o presuntas de los recursos de alzada, "la afirmación de que únicamente ponen fin a la vía administrativa los verdaderos actos o resoluciones administrativas, es decir, las resoluciones expresas -a las que hay que añadir las resoluciones presuntas en los casos de silencio administrativo positivo por prescripción legal expresa (art. 43.3 párrafo primero LRJPAC: la estimación por silencio administrativo tiene a todos los efectos la consideración de acto finalizador del procedimiento)- resulta de lo dispuesto en el artículo 87.1 LRJPAC en relación con el artículo 89.1 de dicho texto legal. En efecto, estableciendo el artículo 87.1 LRJPAC como modo de terminación o finalización del procedimiento administrativo, además del desistimiento, la renuncia y la caducidad, la resolución, ha de entenderse por esta última forma de terminación del procedimiento la resolución expresa, ya que el artículo 89 de la propia LRJPAC fija el contenido de la resolución a que alude el artículo 87.1 y ese contenido sólo puede tener lugar, por obvias razones, en las resoluciones expresas".

Pese a la objeciones que pudieran plantearse a esta argumentación: que el artículo 43 LRJPAC resulta aplicable, como su título indica, a los procedimientos administrativos iniciados a solicitud del interesado, mientras que los procedimientos administrativos sancionadores se inician de oficio por acuerdo del órgano competente (artículo 11 del Reglamento para el ejercicio de la potestad sancionadora, aprobado por Real Decreto 1398/1993, de 4 de agosto) -cuestión que pudiera salvarse con la labor integradora de la jurisprudencia sobre la naturaleza de fictio iuris del silencio administrativo y de sus efectos-; que la invocación al artículo 89 LRJPAC en relación con el artículo 87.1 de esta norma sería más apropiado hacerla al artículo 138.1 LRJPAC, que regula específicamente la resolución que concluye el procedimiento de manera específica para los procedimientos administrativos sancionadores-; y que, respecto de la afirmación que la terminación del procedimiento sancionador sólo puede tener lugar mediante resoluciones expresas, que no es absoluto ob-

13 Dictamen de la Dirección General del Servicio Jurídico del Estado de 25 de septiembre de 2001 (ref: A.G. Medio Ambiente 2/01). Ponente: don Luciano J. Mas Villarroel, sobre "Ejecutividad de resoluciones sancionadoras que hubieran sido recurridas en vía administrativa y desestimados por silencio administrativos los recursos interpuestos". 
jetable, no se corresponde con la resolución que resuelva el recurso de alzada, dado que el procedimiento habrá concluido mediante la resolución expresa que impone la sanción, que es la que se recurre en alzada ${ }^{14}$, que deberá reunir los requisitos del artículo 138 LRJPAC; llegamos a la misma conclusión.

La STS (3르, 6 $\left.6^{\underline{a}}\right)$ de 30 de noviembre de 1993 -recurso 1611/1991- (RJ 1993, 8266) determina que el inicio del dies a quo para la prescripción de las sanciones en materia de tráfico: «sólo comienza una vez que ha ganado firmeza la resolución sancionadora, la cual no se produjo en vía Administrativa al interponerse el recurso de alzada, pues el transcurso de los tres meses siguientes a tal interposición, sin resolución expresa, no determina aquella firmeza, ya que sólo permite la apertura de la vía jurisdiccional por la interposición del proceso contencioso-administrativo». En parecidos términos se pronuncia la STSJ del País Vasco (Contencioso-Administrativo, Sección Tercera) de 9 de diciembre de 1996 -recurso núm. 2212/1995- (RJCA 1996, 2486), resolviendo un caso de posible prescripción de una sanción administrativa que había sido recurrida en alzada, afirma: «Como ya sostuvo este Tribunal en la Sentencia a que hace mérito la Administración (S. 2 febrero 1996 Recurso núm. 1639/1993) [...] la previa adquisición de firmeza de las sanciones [...] no ocurre sino hasta la resolución del recurso de alzada interpuesto [...], pues la tardanza en resolver o el transcurso del plazo de 3 meses que establecía el art. 125 de la LPA (de 1958) para entender desestimado el recurso no producen la firmeza del acto [...] sino que simplemente habilita para entenderlo desestimado por ficción jurídica que permita al particular el acceso a la vía jurisdiccional». De manera explícita y en términos contundentes se pronunció la STS (Contencioso-Administrativo) de 13 de mayo de 1986 (RJ 1986, 4582) declarando que la firmeza de una sanción administrativa no se obtiene por silencio administrativo, ya que el mismo es un mecanismo arbitrado por la Ley para posibilitar el acceso a la vía jurisdiccional, que deja subsistente la obligación de resolver por la Administración.

La STC 243/2006, de 24 de julio, da otra vuelta de tuerca a la cuestión, anulando, por vulnerar el derecho a la tutela judicial efectiva del recurrente, una sentencia desestimatoria de un recurso contra un acto de ejecución de una sanción recurrida en alzada sin haber recaído resolución expresa del recurso sino desestimación presunta por transcurso del plazo de tres meses sin que la Administración contestase, pronunciando: «El art. 115.2 LRJPAC se re-

${ }^{14}$ STS $\left(3^{a}, 5^{\underline{a}}\right)$ de 30 de noviembre de 2004 -recurso de casación en interés de Ley no 97/2002(RJ 2005, 4800). 
fiere al transcurso del plazo de tres meses en el que la Administración ha de resolver el recurso de alzada y notificar lo resuelto. La regla en él contenida, que autoriza a entender desestimado el recurso no resuelto expresamente, salvo en un supuesto ajeno a la cuestión aquí suscitada, sirve de argumento jurídico a la Sentencia impugnada para declarar ajustada a Derecho la firmeza de la sanción, declarada en la orden objeto del recurso contencioso-administrativo. Sin embargo, el enunciado del art. 115.2 LRJPAC no menciona expresamente la firmeza del acto objeto de la alzada; esa firmeza tampoco se presenta como una consecuencia lógica ineludible de lo que el precepto dice expresamente, que es que, transcurrido el plazo para dictar y notificar la resolución, "se podrá entender desestimado el recurso". Sin necesidad de desentrañar si la fórmula impersonal del enunciado legal refiere esa posibilidad sólo al recurrente o también a otros interesados o, incluso, a la propia Administración, basta con efectuar una aproximación a la noción de firmeza en vía administrativa para apreciar que el razonamiento del órgano judicial es insuficiente y no está completo.

En efecto, frente a una resolución firme la Administración, por sí misma, sólo puede declarar de oficio su nulidad en el supuesto de que concurra alguna de las causas tasadas que enumera el art. 62.1 LRJPAC (art. 102.1 LRJPAC), o revocarla, si se interpone el recurso extraordinario de revisión por alguna de las causas igualmente tasadas que recoge el art. 118.1 LRJPAC. Sin embargo, el vencimiento del plazo para resolver un recurso administrativo no deja desapoderada a la Administración frente a lo resuelto por ella misma en el acto impugnado. Cuando se trata del recurso de alzada contra actos expresos, el legislador ha previsto, según hemos expuesto antes, que la expiración del plazo para resolverlo autoriza a tenerlo por desestimado (art. 115.2 LRJPAC), a fin de permitir al recurrente acudir ante los órganos jurisdiccionales del orden contencioso-administrativo (art. 43.3 LRJPAC). Pero el transcurso de dicho plazo no exime a la Administración de su deber de resolver expresamente el recurso (art. 43.1 LRJPAC). Pues bien, tal "resolución expresa posterior al vencimiento del plazo se adoptará por la Administración sin vinculación alguna al sentido del silencio", según prevé el art. 43.4 b) LRJPAC, esto es estimando o desestimando total o parcialmente el recurso de alzada. Las resoluciones de los recursos de alzada, con arreglo al art. 109 a) LRJPAC ponen fin a la vía administrativa y contra ellas no cabrá, dice el art. 115.3 LRJPAC, "ningún otro recurso administrativo, salvo el recurso extraordinario de revisión en los casos establecidos en el art. 118.1".

Estas previsiones, en especial las que determinan que el recurso de alzada contra actos expresos ha de ser resuelto en todo caso, aún extemporánea- 
mente, y sin vinculación alguna al sentido desestimatorio que el recurrente puede atribuir al silencio de la Administración a fin de acudir a los Tribunales, excluyen que la resolución objeto de un recurso de alzada pueda alcanzar firmeza hasta que no se desestime éste expresa y totalmente, pues hasta ese momento la Administración puede decidir cuantas cuestiones plantee el recurso, tanto de forma como de fondo, de modo congruente con las peticiones formuladas por el recurrente (art. 113.3 LRJPAC). El deber de la Administración de resolver el recurso y su potestad de hacerlo en sentido estimatorio, revocando o anulando totalmente la resolución impugnada en alzada, resultan incompatibles con la atribución a ésta de la nota de firmeza antes de la resolución expresa de aquél y esa incompatibilidad, que se inicia con la interposición temporánea del recurso, subsiste en tanto no se produzca esa resolución expresa, con independencia de que ello tenga lugar dentro del plazo legal concedido a la Administración o una vez expirado éste.

Tampoco el transcurso del plazo establecido en el art. 46.1 LJCA para interponer el recurso contencioso-administrativo contra actos presuntos sin hacer uso del mismo permite lógicamente atribuir firmeza a la resolución administrativa combatida en el recurso de alzada no resuelto [...]. La interposición del recurso contencioso-administrativo dentro del plazo de seis meses fijado en el art. 46.1 LJCA no exime a la Administración de su deber de resolver el recurso de alzada ni impide que la resolución del mismo sea totalmente estimatoria, como se desprende con claridad de los arts. 36.4 y 76 LJCA, que dan por supuesta la eventualidad de que el cumplimiento tardío por la Administración de su deber de resolver se produzca una vez promovido el recurso contencioso-administrativo; otro tanto sucede con la expiración de aquel plazo sin que llegue a interponerse el recurso jurisdiccional, de modo que ninguno de esos dos hechos supone la firmeza del acto administrativo originario. La incompatibilidad lógica entre la pendencia en la resolución de la alzada y la firmeza del acto administrativo expreso objeto de la misma subsiste, en consecuencia, aún expirado el plazo de seis meses a que alude el art. 46.1 LJCA y al margen de si se ha formulado o no el recurso contencioso-administrativo».

Del contenido del artículo 138.3 LRJPAC se deduce que los actos administrativos sancionadores únicamente serán inmediatamente ejecutivos cuando hayan sido dictados por un órgano que carezca de superior jerárquico. En caso contrario, la ejecutividad de la sanción queda postergada a la resolución del recurso de alzada o bien al momento de finalización del plazo para recurrir en vía administrativa, porque el artículo 138.3 requiere el agotamiento de la vía administrativa, lo que ha sido identificado por la jurisprudencia y algunos autores con la firmeza del acto administrativo sancionador, sin que los 
efectos de lo dispuesto por el artículo 138.3 no afectan, sin embargo, a la posible interposición del recurso contencioso-administrativo ${ }^{15}$.

En esta línea crítica con la inactividad de la Administración tratada de solventar de alguna manera mediante el silencio administrativo, la STS $\left(3^{\underline{a}}, 2^{\underline{a}}\right)$ de 23 de marzo de 1998 -recurso de apelación núm. 1308/1992- (RJ 1998, 3033), niega ejecutividad a una sanción sobre la que se solicitó su suspensión aportando garantía y no recibió contestación, desestimando el argumento de la Administración de que el silencio era de sentido negativo y que la garantía carecía de virtualidad, declarando: "ha de recordarse que, como tiene declarado esta Sala, el silencio administrativo negativo es una institución exclusivamente dirigida a garantizar los derechos de los ciudadanos frente a la inactividad de la Administración y por lo tanto no puede servir para reportar a ésta ventaja alguna, como consecuencia del incumplimiento de su deber de resolver expresamente. Es más, la denegación presunta puede producirse cuando el silencio afecta exclusivamente a la ausencia de resolución, pero cuando la falta de pronunciamiento se extiende a otros actos, como los de impulso del procedimiento o subsanación de defectos, el mutismo de la Administración no sólo no tiene por qué producir la presunción negativa, sino que, en sentido opuesto, no se excluye la posibilidad de aplicar los principios generales sobre el tácito consentimiento, cuando las circunstancias concurrentes así lo evidencien".

En el caso de autos la aceptación por la Administración del aval presentado con el recurso de alzada, unido al paso del tiempo sin resolución expresa sobre la suspensión solicitada, no puede ser entendido como presunta denegación de esta última. En efecto el aval es un documento expedido por un tercero, que produce gastos para el interesado desde el momento de su expedición y que si no iba a surtir efectos garantizadores de la deuda constituida por la sanción impuesta, debió ser devuelto lo antes posible al sancionado para evitar que aquellos gastos se prolongasen inútilmente. Por otra parte si como dice el Abogado del Estado, el documento aportado carecía de virtualidad para surtir los efectos de garantía que se pretendían y caso de no devolverlo,

\footnotetext{
${ }^{15}$ Como ha declarado el Pleno de la Sala Tercera del Tribunal Supremo en Sentencia de 7 de marzo de 2005 -recurso de casación núm. 715/1999- con tres votos particulares que defienden que la suspensión de la sanción debe extenderse hasta la resolución del recurso jurisdiccional. LITAGO LLEDO, Rosa: "Los efectos derivados de la inclusión de las sanciones en la deuda tributaria: Problemas de constitucionalidad. Comentario al ATJS de Cataluña de 28 de febrero de 1996. Jurisprudencia Tributaria Aranzadi. Tomo. III Parte Estudio págs. 1577 y siguientes.
} 
se debió advertir al interesado para que pudiera subsanarlo. Lo que no puede admitirse es que generada en el recurrente la razonable confianza en que la sanción no iba a ser ejecutada, por estar solicitada la suspensión y garantizado el cobro, sin advertencia o reserva alguna por parte de la Administración y sin que ésta resolviera sobre lo pedido, se pase directamente a la vía de apremio, que como privilegio de autotutela, no debe iniciarse cuando conste la voluntad de pago, situación que constaba en el expediente”.

De ello se deduce que la falta de resolución por parte de la Administración del recurso de alzada dentro del plazo establecido no puede en ningún caso determinar la firmeza de la resolución sancionadora. Al quedar subsistente la obligación de la Administración de resolver de forma expresa el recurso interpuesto, en tanto no se resuelva (y notifique al administrado), la resolución sancionadora no pondrá fin a la vía administrativa, y en consecuencia, no tendrá la consideración de ejecutiva ${ }^{16}$.

En vista de lo expuesto, puede concluirse que la firmeza de las sanciones administrativas que hayan sido recurridas en alzada no se obtiene sino hasta el momento en que se ha desestimado de manera expresa el recurso de alzada por el órgano competente, momento a partir del cual será ejecutiva y por tanto ejecutable.

II.2) LA INCIDENCIA DE LA JURISPRUDENCIA CONSTITUCIONAL EN EL MOMENTO A PARTIR DE QUE SON EJECUTIVAS LAS SANCIONES ADMINISTRATIVAS. LA IMPORTANCIA DE LA DISTINCIÓN JURISPRUDENCIAL ENTRE EJECUTIVIDAD DEL ACTO Y REALIZACIÓN DE ACTOS DE EJECUCIÓN MATERIAL DEL MISMO

Un argumento se repite con insistencia en los pronunciamientos de la Sala Tercera del Tribunal Supremo: "tratándose de resoluciones administrativas, debe distinguirse entre ejecutividad y actividad de ejecución; y que lo primero expresa una calidad de la resolución, consistente en la posibilidad de ser llevada mediante actos materiales de ejecución, mientras que lo segundo son esos actos materiales por los que se lleva a la práctica la resolución, y que son algo distinto de esta última aunque arranquen de ella. $Y$ ha dicho que la ejecutividad no es en principio contraria al derecho reconocido en el artículo 24 $\mathrm{CE}, \mathrm{y}$ que lo decisivo para que pueda ser procedente, desde la perspectiva de dicho precepto constitucional, será su posibilidad de control jurisdiccional.

16 SAEZ HIDALGO, Ignacio: "Efectos del silencio administrativo en vía de recurso: la prescripción de sanciones”. Actualidad Jurídica Aranzadi núm. 402, Agosto, 1999, pgs. 1 -5. 
Respecto de esto último, ha afirmado, con base en la doctrina contenida en la STC 66/1984, que, por lo que hace a la ejecutividad, la tutela judicial se satisface facilitando que dicha ejecutividad pueda ser sometida ante un tribunal, para que éste, con la información y contradicción que resulte menester, resuelva sobre la suspensión. También ha recordado que la STC 78/1996, de 20 de mayo, declaró: «el derecho a la tutela se extiende a la pretensión de suspensión de la ejecución de los actos administrativos que, si formulada en el procedimiento administrativo, debe permitir la impugnación de su denegación, y, si se ejercitó en el proceso, debe dar lugar en el mismo a la correspondiente revisión específica. Tras lo anterior, se ha sentado la conclusión de que el derecho a la tutela judicial se satisface cuando, antes de la ejecución, se permite someter a la decisión de un tribunal la ejecutividad, para que este resuelva sobre la suspensión. Y que, por tanto, se vulnera ese derecho fundamental, no cuando se dictan actos que gozan de ejecutividad, sino cuando, en relación a los mismos, se inician actos materiales de ejecución sin ofrecer al interesado la posibilidad de instar judicialmente la suspensión de esa ejecutividad"17.

En términos de la STS $\left(3^{\mathrm{a}}, 6^{\mathrm{a}}\right)$ de 26 de octubre de 2005 -recurso de casación en interés de Ley núm. 61/2004- (RJ 2005, 7116): «la sentencia 66/1984, de 6 de junio, del Tribunal Constitucional, declara la constitucionalidad de la autotutela ejecutiva en materia de derecho sancionador y, por ende, la ejecutividad de los actos administrativos sancionadores como no contraria a la presunción de inocencia ni al derecho a la tutela judicial efectiva, siempre que la ejecución pudiera ser sometida a la decisión de un Tribunal de Justicia y que éste pudiera resolver sobre su suspensión y de ahí, también, que la sentencia del propio Tribunal 78/1996, de 20 de mayo, añada que "mientras se toma aquella decisión (se refiere a la que resuelva sobre la suspensión solicitada), no pueda ésta impedirse ejecutando el acto, con lo cual la Administración se habría convertido en Juez". Si, pues no podía procederse a la ejecución de la sanción impuesta hasta que, impugnada la liquidación y solicitada la suspensión en ella contenida, pudiera resolver sobre la misma la Sala Jurisdiccional ante la que el recurso hubiera sido planteado, es claro que, mientras tanto, no podía declararse la ejecutividad de la sanción».

17 SSTS (3 $\left.3^{\underline{a}}, 7^{\mathrm{a}}\right)$, de 12 noviembre 1999 -recurso de casación núm. 8267/1995- (RJ 1999, 10050), de 2 enero 2001 -recurso de casación núm. 6792/1996- (RJ 2001, 1144), de 16 de enero de 2001 -recurso de de casación núm. 7134/1996- (RJ 2001, 4413), de 17 julio 2001 -recurso de casación núm. 503/1997- (RJ 2001, 6916), de 11 octubre 2002 -recurso de casación núm. 7376/1998- (RJ 2002, 10220), de 14 noviembre 2002 -recurso de casación núm. 8966/1998- (RJ 2002, 9925), de 5 octubre 2004 -recurso de casación núm. 6633/2000- (RJ 2004, 6299), y de 24 noviembre 2004 -recurso de casación núm. 3071/2001- (RJ 2004, 8173). 
Este planteamiento, tributario de la doctrina italiana, distingue entre la ejecutividad del acto o autotutela declarativa, resoluciones administrativas que "per se" alteran una realidad jurídica preexistente, y su ejecutoriedad o autotutela ejecutiva, actuaciones materiales de ejecución de la resolución previa que es lo que realmente se suspende. Para su mejor aplicación debe completarse con la doctrina de la STC 78/1996 que expresamente señala, y lo hace más allá del estricto ámbito del derecho sancionador, que tampoco podrá ejecutarse el acto administrativo en el "interin" que media entre el momento en el que se dicta y el previo a la interposición del recurso jurisdiccional pues en ese caso se frustraría el derecho reconocido en el art. 24.1 CE (STS 19-10-1999 rec. $\mathrm{n}^{\mathrm{o}} 7793 / 98$ ). La consecuencia de lo anterior es la de que la petición de suspensión provoca como regla general la suspensión de las actividades de ejecución acto y corresponderá a la recurrente la carga de la prueba, al menos indicaría, sobre la posible causación de perjuicios irreversibles derivados de su ejecución: STS 5-6-2001 (RJ 2001, 4462) rec. no 2194/98 y ATS S-2-2001 (RJ 2001, 1398) rec. no 1599/200018». Esta doctrina encuentra continuidad en la STC 243/2006, de 24 de julio, que impone un severo correctivo a la Administración, pese a afirmar que: "Es indudable que esa ejecutividad, que según hemos declarado reiteradamente no resulta, en sí misma, contraria a la Constitución (STC 66/1984, de 6 de junio, F.J. 3), es sin embargo, relevante desde la perspectiva del art. 24.1 CE. En este sentido hemos dicho que la ejecutividad resulta compatible con las exigencias del artículo 24.1 $\mathrm{CE}$, siempre que la misma pueda ser sometida al control de los Tribunales (ATC 48/2004, de 12 de febrero, F.J. 2; y STC 291/2000, de 30 de noviembre, F.J. 5). De la apreciación de que es constitucionalmente legítima la ejecutividad de los actos administrativos no hemos exceptuado a los que tienen carácter sancionador, en tanto no se impida, dificulte o condiciones el posible recurso jurisdiccional contra ellos ni se menoscabe la posibilidad de solicitar y obtener de los Tribunales la suspensión cautelar (STC 341/1993, de 18 de noviembre, F.J. 12)".

El argumento de vincular la posibilidad de ejecutar una sanción administrativa mediante el establecimiento de la vía de apremio a la garantía de su control jurisdiccional, incluso de manera cautelar, ha sido también utilizado por la jurisprudencia comunitaria. La STJCE Luxemburgo (Sala Quinta) de 11 de enero de 2001 Kofisa Italia. Cuestión Prejudicial. Asunto C-1/1999, y la STJCE Luxemburgo (Sala Quinta) de 11 de enero de 2001 Siples. Cuestión

18 Auto de la Audiencia Nacional (Contencioso-Administrativo, Sección 6 $6^{\mathbf{a}}$ ) de 24 abril 2002 (JUR 2002, 120909). 
Prejudicial. Asunto C-226/1999, consideran conforme al Derecho Comunitario que las autoridades administrativas puedan ejecutar una decisión mediante el establecimiento del procedimiento de apremio, si bien precisa que «tal disposición no puede limitar el derecho a una tutela judicial efectiva. En efecto, la exigencia de un control jurisdiccional de cualquier decisión de una autoridad nacional constituye un principio general de Derecho comunitario que deriva de las tradiciones constitucionales comunes de los Estados miembros y que está consagrada en los artículos 6 y 13 del Convenio Europeo para la Protección de los Derechos Humanos y de las Libertades Fundamentales (sentencias de 15 de octubre de 1987, Heylens y otros, 222/86, Rec. pg. 4097, apartado 14, y de 3 de diciembre de 1992, Oleificio Borelli/Comisión, C-97/91, Rec. pg. I-6313, apartado 14)».

La conclusión es clara, la ejecutividad de la sanción se produce en el momento en que recae resolución expresa del recurso de alzada interpuesto contra ésta poniendo fin a la vía administrativa, por lo que un posible recurso jurisdiccional interpuesto contra ésta con la solicitud de la medida cautelar de suspensión de su eficacia no afecta a la ejecutividad del acto administrativo. Cuestión distinta es que la Administración proceda a realizar actos materiales de ejecución de la sanción ejecutiva como la traba de un embargo sobre bienes tras el inicio de la vía de apremio ${ }^{19}$ antes de que el tribunal se haya pro-

\footnotetext{
${ }^{19}$ Como el caso resuelto por la STS (3 $\left.3^{\mathrm{a}}, 7^{\mathrm{a}}\right)$, de 20 abril 2004 -recurso de casación núm. 1056/1998- (RJ 2004, 3324), declarando que a las sanciones, les "son aplicables, como es bien conocido, las normas referentes a las penas como consecuencia de la aplicabilidad al Derecho Administrativo sancionador, con ciertos matices, de los principios constitucionales que rigen en materia penal, en cuanto que sanciones y penas manifestaciones son del ius puniendi del Estado, según criterios reiteradamente expuestos en la doctrina de esta Sala, siendo de destacar que la STC $66 / 84$, de 6 de junio [...] si bien declara la constitucionalidad de la autotutela ejecutiva en materia de Derecho Administrativo sancionador, y por tanto, la ejecutividad de los actos administrativos sancionadores como no contraria a la presunción de inocencia ni al derecho a la tutela judicial efectiva, añade que ello sucederá siempre que la ejecución pudiera ser sometida a un Tribunal de Justicia, y que éste pudiera resolver sobre la suspensión (porque la justicia cautelar forma parte del derecho a la tutela judicial efectiva, como se reflejó, por ejemplo en el Auto, de esta Sala de 19 de abril de 2002 y en tantas otras resoluciones), lo que también coincide con la STC 78/96, de 20 de mayo conforme a la que no puede impedirse la suspensión a base de ejecutar el acto [...] En suma pues, impugnándose, en concreto, el embargo -la vía ejecutiva- en cuanto al importe de las sanciones tributarias sólo en lo que a ellas respecta, según la demanda y en razón a que se incluyen en la «composición» de las liquidaciones y que penden de recurso o de reclamación, lo que nadie ha negado, obvio resulta la procedente aplicación del artículo 24 de la Constitución en cuanto a presunción de inocencia y en cuanto a la omisión de la tutela judicial efectiva, aquella proclamada también en el artículo 137 de la Ley 30/92, máxime cuando, en cualquier caso, los preceptos en que se apoya el recurso de casación y que se señalan como infringidos por
} 
nunciado sobre la medida cautelar solicitada, conducta que la jurisprudencia considera contraria al derecho a la tutela judicial efectiva -que incluye el derecho a la tutela cautelar-, consagrado en el artículo 24 de la Constitución ${ }^{20}$.

\section{DE LA EJECUTIVIDAD DE LA RESOLUCIÓN A LA ACTIVIDAD DE EJECUCIÓN DE LA SANCIÓN ADMINISTRATIVA}

Es bien sabido que la ejecutividad del acto administrativo estimada por la doctrina como potencia obligatoria del mismo o carga de imposición de conductas frente a terceros, se basa en la presunción de que el acto es legítimo y por ello puede procederse ulteriormente a su realización incluso en contra de la voluntad de sus destinatarios. Supone, en fin, que un acto de la Administración una vez completado, es susceptible de producir las consecuencias que le son propias a través de diversos medios coercitivos empleados por la propia Administración, entre ellos la ejecución subsidiaria ${ }^{21}$.

Una vez agotada la vía administrativa en el procedimiento administrativo sancionador al haberse desestimado, total o parcialmente, de manera expresa mediante la correspondiente resolución del órgano competente del recurso de alzada interpuesto contra el acto sancionador susceptible de ello, la sanción es firme y por tanto, ejecutiva y ejecutable, por lo que ante el incumplimiento voluntario de ésta por el sancionado, cabe iniciar el proceso de ejecución, mediante la realización de esos propios actos materiales por los que ésta se lleva a la práctica, a que se refiere la jurisprudencia. Actos materiales de ejecución forzosa que podrán realizarse por las propias Administraciones Públicas, a través de sus órganos competentes, previo apercibimiento y con las salvedades que hiciéramos en un apartado anterior, como manifestación de la autotutela ejecutiva del que se dota a éstas para el cumplimiento de los fines

la sentencia de instancia, incluido el del artículo 34 de la Ley General Presupuestaria han de ser interpretados y aplicados en consonancia con aquellos derechos fundamentales, que, en efecto, han sido vulnerados en la actuación administrativa concreta que se impugnó en la instancia y que la sentencia anuló por tal razón, lo que impone la desestimación del motivo, en vista, además, de la fuerza expansiva de tales derechos fundamentales”.

${ }^{20}$ Una visión sobre el estado de la cuestión en el Informe de la Abogacía del Estado sobre "Ejecutividad de las resoluciones administrativas sancionadoras confirmadas por Sentencias", elaborado el 29 de mayo de 2002 por D. David Melgar García, Abogado del Estado-Adjunto en el Ministerio de Economía.

${ }^{21}$ STS (Contencioso-Administrativo) de 1 de febrero de 1989 (RJ 1989, 792). 
de interés general (STC 22/84), a través de los diversos medios previstos en el artículo 96 LRJPAC, entre los que se encuentra el procedimiento de apremio.

El artículo 93 LRJPAC, dispone en su apartado primero que: «Las Administraciones Públicas no iniciarán ninguna actuación material de ejecución de resoluciones que limite derechos de los particulares sin que previamente haya sido adoptada la resolución que le sirva de fundamento jurídico», determinando el precepto en su apartado segundo que: «el órgano que ordene un acto de ejecución material de resoluciones estará obligado a notificar al particular interesado la resolución que autorice la actuación administrativa».

El precepto nos da las claves de la ejecución forzosa por la Administración de sus actos: la existencia de un acto administrativo ejecutivo, que en el caso de las sanciones susceptibles de ser recurridas en alzada se produce en el momento en que adquiera firmeza en vía administrativa -en el caso que nos ocupa, cuando sea desestimado de manera expresa el recurso de alzada interpuesto contra la resolución sancionadora (con la cautela que deberá adoptar el órgano ejecutante de esperar el transcurso del plazo de impugnación jurisdiccional de la sanción por si se solicitare por el interesado la suspensión de la misma y en este caso la espera del pronunciamiento del tribunal sobre la procedencia de ésta)-, y su notificación en tiempo y forma al interesado.

Esta resolución, que es condición necesaria para iniciar actuaciones materiales limitativas de derechos, no es suficiente para la práctica de las mismas, porque hace falta un título ejecutivo que las ampare, a través de alguna de las modalidades previstas en la $\mathrm{Ley}^{22}$, entendido como aquel acto jurídico constatado documentalmente, al que la ley confiere virtualidad para abrir directamente el proceso de ejecución ${ }^{23}$, que en el caso del establecimiento de la vía de apremio como medio de ejecución nos remite a la aplicación de su regulación específica ( $\mathrm{y}$ a la providencia de apremio), que trataremos en el apartado siguiente. En términos de la STS $\left(3^{\mathbf{a}}, 3^{\underline{a}}\right)$ de 3 de mayo de 2004 -recurso de casación núm. 3993/2000- (RJ 2004, 2561): «La Administración, al actuar la potestad administrativa de ejecución forzosa, está sometida rigurosamente al

${ }^{22}$ MENENDEZ REXACH, Ángel: Procedimientos Administrativos: finalización y ejecución. En VV.AA. Jesús Leguina Villa y Miguel Sánchez Morón (Directores): La nueva Ley de Régimen Jurídico de las Administraciones Públicas y del Procedimiento Administrativo Común”. Editorial Tecnos. Madrid, 1993, p. 268.

${ }^{23}$ PÉREZ BORREGO, Gregorio: Arbitraje de elecciones y procesos judiciales en materia electoral. Editorial Comares. Granada, 1999, p. 119. 
principio de legalidad, de modo que, en aplicación del artículo 93 de la Ley procedimental administrativa, la ejecución requiere de un previo acto habilitante y debe limitarse a realizar el contenido del acto administrativo que el obligado no ha cumplido, sin poder transformar o alterar dicho contenido y sin añadir ninguna obligación nueva [...] pues la voluntad de los órganos de la Administración es ineficaz si no descansa en la creación de un título ejecutivo previo, constituido por una previa resolución condenatoria acordada en el correspondiente procedimiento en el que como mínimo ha de existir una audiencia del interesado y cuya resolución es ejecutiva, salvo suspensión acordada conforme a derecho, todo ello según lo determinan las normas comunes y especiales de los procedimientos administrativos; y tanto es así, que aún en materia tributaria lo que se ejecutan son liquidaciones practicadas y ejecutivas previa audiencia de la parte que son verdaderas resoluciones, cuyo impago [...] abre la vía de ejecución forzosa sea en período voluntario o de apremio [...], si bien debiéndose señalar la imprecisión de ambas normas, al equiparar la apertura del proceso de ejecución forzosa con el título en que se funda, que es el acto administrativo de fondo que declara la existencia y obligatoriedad del pago de la deuda estableciendo la obligación que es ejecutiva, siendo equiparable este acto administrativo de fondo, condenatorio al pago, a la sentencia judicial ejecutoria que es el título que se lleva a efecto por el procedimiento de ejecución forzosa; debiéndose distinguir el título ya formado como consecuencia de todo el procedimiento en el que se produce, de la petición de apertura del proceso de ejecución del mismo; cuyo lugar de tal petición de apertura de la ejecución forzosa [...] por lo mismo, es de obligada y natural observancia configurar la petición de apertura del procedimiento administrativo de ejecución forzosa con referencia al acto administrativo ejecutivo que establezca la obligación que se ha de hacer efectiva y cuya regularidad en orden a verificar su eficacia ejecutiva se halla a cargo del órgano de gestión encargado de hacer efectiva la ejecución forzosa, pues la misma ha de atenerse al principio de legalidad».

\section{EL ESTABLECIMIENTO DE LA VÍA DE APREMIO COMO ME- DIO DE EJECUCIÓN DE LAS SANCIONES ADMINISTRATIVAS}

El artículo 96.1.a) LRJPPAC contempla el apremio sobre el patrimonio como medio de ejecución forzosa por las Administraciones Públicas de los actos por ellas acordados, previsión que se completa con la del artículo 97.1 LRJPAC que remite al procedimiento recaudatorio en vía ejecutiva, lo que nos conduce al Reglamento General de Recaudación, cuyo artículo 1.3 establece que "El cobro en período ejecutivo de los recursos a los que se refiere el pá- 
rrafo anterior se efectuará por el procedimiento de apremio regulado en la Ley 58/2003, de 17 de diciembre, General Tributaria, y en este Reglamento", y en su artículo 1.2 al disponer que este Reglamento será de aplicación en los términos previstos en el artículo 1 LGT.

Llegados a este punto, encontramos que las sanciones administrativas cuyo medio de ejecución sea el apremio sobre el patrimonio del ejecutado se regirán por la normativa tributaria, aunque sin dejar de tener en consideración su carácter administrativo. Es conveniente hacer esta precisión, dada la autonomía de los procedimientos tributarios respecto de los administrativos, aunque los primeros sean de naturaleza administrativa, al igual que el procedimiento de apremio en materia tributaria, como se encargan de proclamar reiteradamente la LGT y el RGR, y la Disposición Adicional quinta LRJPAC que remite la regulación de los procedimientos administrativos en materia tributaria a su regulación específica y, en su defecto y con carácter supletorio, a las disposiciones de la Ley 30/1992, de 26 de noviembre, si bien la Sentencia del Pleno de la Sala Tercera del Tribunal Supremo de 7 de marzo de 2005 -recurso de casación núm. 715/1999- (RJ 2005, 3861) precisa: «En la Ley 30/1992, siguiendo, según su Exposición de Motivos, el principio de presunción de inocencia o de no responsabilidad del contribuyente, se estableció, en sus artículos 107.4 (que, en conexión con la Disposición Adicional quinta, defiere las reclamaciones económico administrativas, $y$, en general, los procedimientos administrativos en materia tributaria, a la regulación contenida en su legislación específica -si bien parece que debe interpretarse en el sentido de que sólo se hace relación al 'procedimiento' y no a los aspectos sustantivos de la cuestión-), 137.1 y 138.1.1 que "los procedimientos SANCIONADORES respetarán la presunción de no existencia de responsabilidad administrativa mientras no se demuestre lo contrario" y que "la resolución será ejecutiva cuando ponga fin a la vía administrativa"».

Esta circunstancia obliga a una labor interpretativa que permita encajar actos administrativos sancionadores en los supuestos de hecho previstos por la normativa tributaria que regula el procedimiento de apremio, que trataremos en el siguiente apartado.

\section{LA ¿DIFÍCIL? CORRESPONDENCIA DE LOS CONCEPTOS DE LA LRJPAC EN LOS PROCEDIMIENTOS DE EJECUCIÓN DINE- RARIA DE SANCIONES ADMINISTRATIVAS DE LA LGT}

El artículo 163.1 LGT proclama la naturaleza exclusivamente administrativa del procedimiento de apremio, y otorga con carácter exclusivo la compe- 
tencia para entender del mismo y resolver todas sus incidencias a la Administración tributaria.

En sintonía con el artículo 93.1 LRJPAC, que dispone que: «Las Administraciones Públicas no iniciarán ninguna actuación material de ejecución de resoluciones que limite derechos de los particulares sin que previamente haya sido adoptada la resolución que le sirva de fundamento jurídico», el artículo 167.2 LGT prescribe que: "La providencia de apremio será título suficiente para iniciar el procedimiento de apremio y tendrá la misma fuerza ejecutiva que la sentencia judicial para proceder contra los bienes y derechos de los obligados tributarios", y el artículo 70.1 del RGR define la providencia de apremio como "el acto de la Administración que ordena la ejecución contra el patrimonio del obligado al pago". Como ha declarado la STS $\left(3^{\underline{a}}, 2^{\underline{a}}\right)$ de 3 de junio de 1995 -recurso 3778/1991- (RJ 1995, 6032): «la apertura, estrictamente hablando, del procedimiento de apremio exige unos presupuestos habilitantes: el "material", consistente en el impago en período voluntario, y el "formal", constituido por el Título ejecutivo» 24 .

Aplicando esta consideración a la materia que tratamos, resulta que el presupuesto material del procedimiento de apremio para la ejecución de sanciones administrativas se concreta en el incumplimiento por el sancionado de su obligación de abonar a la Administración sancionadora el importe de la multa en el plazo otorgado una vez que la sanción es firme en vía administrativa, y por tanto, goza de la ejecutividad que le otorgan los artículos 94 y 138.1 LRJPAC, y el presupuesto formal o título ejecutivo lo cumple la providencia de apremio, que es el título que abre este procedimiento de ejecución. La especial naturaleza del procedimiento administrativo de apremio a través del cual el Ente Público titular del crédito, procede, sin necesidad de previa resolución judicial de condena del deudor, a la ejecución de los bienes de éste para transformarlos en una suma que le permita hacerse cobro del débito insatisfecho, por falta de prestación del sujeto obligado dentro del período voluntario de recaudación, determina, de una parte, que para que pueda iniciarse tal procedimiento de apremio será necesario la existencia de un título ejecutivo, esto es, un título que documente el derecho de crédito de la Administración y

\footnotetext{
${ }^{24}$ En idénticos términos se pronuncia la STSJ de Castilla y León/Burgos (Contencioso-Administrativo) de 19 de junio de 2000 -recurso 1354/1998- (RJCA 2000, 1177): "el procedimiento de recaudación en vía de apremio requiere para su iniciación, la concurrencia de un presupuesto material concretado en el incumplimiento o no satisfacción de la deuda tributaria en el plazo voluntario de ingreso y un presupuesto formal o título ejecutivo".
} 
legitime a ésta, como acreedora, para obtener coactivamente la satisfacción de su derecho; y de otra parte, que una vez iniciado este procedimiento los motivos de oposición al mismo se hallan legalmente tasados ${ }^{25}$.

La normativa reguladora del procedimiento apremio, a la que para la ejecución de actos administrativos en virtud de los cuales hubiese de satisfacerse una cantidad líquida, remite expresamente el artículo 97.1 LRJPAC, establece como presupuesto -o "requisito material" a que se refiere la jurisprudenciapara el inicio del procedimiento ejecutivo el vencimiento del plazo de ingreso de la deuda en periodo voluntario sin que ésta se haya realizado. Así, el artículo 161.3 LGT establece que iniciado el período ejecutivo, la Administración tributaria efectuará la recaudación de las deudas liquidadas o autoliquidadas a las que se refiere el apartado 1 de este artículo por el procedimiento de apremio sobre el patrimonio del obligado al pago, disponiendo el artículo 69 del RGR, titulado "Recaudación en período ejecutivo", en su apartado primero que la recaudación en período ejecutivo se inicia de acuerdo con lo dispuesto en el artículo 161.1 LGT, en relación con los importes no satisfechos en período voluntario ${ }^{26}$. Por su parte, el artículo 69.2 RGR, en clara sintonía con el artículo 93 LRJPAC, determina que la notificación de la providencia de apremio determina el inicio del procedimiento de apremio (artículo 69.2 RGR).

El impago de la deuda en periodo voluntario abre el periodo ejecutivo, que permite a la Administración tributaria cumplir el requisito formal (en términos de la jurisprudencia), que se materializará mediante el dictado de la providencia de apremio, que como ha declarado en interés de ley la STS ( $3^{a}$, $\left.2^{\underline{a}}\right)$ de 22 de febrero de 2005 -recurso de casación en interés de Ley núm. 3448/2001- (RJ 2005, 2203): «es un pleno título ejecutivo. Despacha la ejecución, abre la ejecución directa y coactiva sobre el patrimonio del deudor, declara la voluntad administrativa de proceder ejecutivamente -es una manifes-

${ }^{25}$ STSJ de Baleares (Contencioso-Administrativo) de 16 de abril de 1996 (RJCA 1996, 399).

${ }^{26}$ El artículo 161 LGT, titulado "Recaudación en período ejecutivo", dispone que "El período ejecutivo se inicia:

a) En el caso de deudas liquidadas por la Administración tributaria, el día siguiente al del vencimiento del plazo establecido para su ingreso en el artículo 62 de esta Ley.

b) En el caso de deudas a ingresar mediante autoliquidación presentada sin realizar el ingreso, al día siguiente de la finalización del plazo que establezca la normativa de cada tributo para dicho ingreso o, si éste ya hubiere concluido, el día siguiente a la presentación de la autoliquidación. $[\ldots]$. 
tación de la autotutela ejecutiva de las Administraciones Públicas- y comporta el derecho-deber de exigir la deuda de aquella manera coactiva, es decir, compulsivamente sobre el patrimonio. Es pues, la típica voluntad administrativa ejecutiva; y es completa».

La normativa reguladora del procedimiento administrativo de apremio, de carácter indudablemente tributario aunque proclame su carácter expansivo a otras ramas del ordenamiento, debe conjugarse con los principios del procedimiento administrativo sancionador en los casos de establecimiento de la vía de apremio como medio de ejecución de las sanciones administrativas de carácter pecuniario, actos administrativos que no tienen naturaleza de liquidaciones tributarias, pero cuyo impago en periodo voluntario abre el periodo ejecutivo -al tener la consideración de deuda a los efectos del Reglamento General de Recaudación (artículo 2 RGR) - y notificada la providencia de apremio, el apremio como procedimiento administrativo de ejecución.

La solución dada por la jurisprudencia pasa por identificar la obligación derivada de la sanción pecuniaria con la liquidación tributaria, puesto que ambas determinan la obligación del interesado de ingresar unas cantidades en el Tesoro Público ${ }^{27}$. Así, la STS (Contencioso-Administrativo, Sección 8 $8^{\text {a }}$ ) de 25

${ }^{27}$ A título meramente ilustrativo la STS $\left(3^{3}, 6^{\mathrm{a}}\right)$ de 26 de octubre de 2005 -recurso de casación en interés de Ley núm. 61/2004- (RJ 2005, 7116) resuelve un recurso contra la sentencia que anula liquidaciones de sanciones de la Agencia de Protección de Datos; la STS (3 $\left.3^{\mathbf{a}}, 5^{\mathbf{a}}\right)$ de 31 de diciembre de 2001, dictada en un recurso de casación en interés de Ley (RJ 2001, 10130) y la STS (3 $\left.3^{\mathrm{a}}, 5^{\mathrm{a}}\right)$ de 17 enero 1996 -recurso de apelación núm. 3584/1991- (RJ 1996, 27) resuelven impugnaciones del establecimiento de la vía de apremio derivados de sanciones urbanísticas; STS (3ª , $6^{\mathrm{a}}$ ) de 20 de febrero de 2001 -recurso de casación núm. 6006/1996- (RJ 2001, 5382) impugnación de sanciones en materia de juego; la STS (3 $\left.3^{\mathbf{a}}, 3^{\mathbf{a}}\right)$ de 14 de marzo de 1996 -recurso de apelación 1777/1989- (RJ 1996, 2561) resuelve un supuesto de sanción en materia de aguas; la STS (Contencioso-Administrativo, Sección 8ª), de 25 junio 1990 (RJ 1990, 4972) anula una liquidación derivada de una sanción urbanística y la STS (Contencioso-Administrativo) de 29 de enero de 1988 (RJ 1988, 172) desestima el recurso interpuesto contra una providencia de apremio que dimana de una sanción urbanística donde se argumentó que no se había notificado la resolución sancionadora porque en el expediente queda plenamente acreditada la notificación de la sanción.

En materia de sanciones pecuniarias de tráfico STSJ de Cataluña (Contencioso-Administrativo, Sección Segunda) de 23 de febrero de 2005 -recurso 3148/1998- (JUR 2005, 173888); STSJ de Castilla y León/Valladolid (Contencioso-Administrativo, Sección Primera) de 5 de mayo de 2004 -recurso 3885/1998- (JUR 2004, 279636); STSJ de Murcia (Contencioso-Administrativo, Sección Segunda) de 13 de noviembre de 2003 -recurso 993/00- (JUR 2004, 76659); STSJ de Madrid (Contencioso-Administrativo, Sección Segunda) de 29 de abril de 2003 -recurso 1629/1996- (JUR 2003, 267547); STSJ de Cataluña (Contencioso-Administrativo, Sección Tercera) de 11 de noviembre de 2002 -recurso 1215/1998- (JUR 2003, 100310); STSJ de Galicia (Con- 
junio 1990 (RJ 1990, 4972) declara: «Que según se desprende de lo dispuesto en [...] la Ley Tributaria, la notificación en forma de las liquidaciones, y lógicamente, por analogía de los actos sancionatorios que impongan al sancionado pago de cantidad determinada en concepto de multa, constituyen al sujeto pasivo en la obligación de satisfacer las deudas tributarias; pago que podrá hacerse en período voluntario [...] con la notificación directa de la deuda al sujeto pasivo; de modo que la vía de apremio sólo podrá válidamente ser comenzada cuando, vencido el plazo de ingreso voluntario, no se hubiere satisfecho la deuda tributaria. Por otro lado, los arts. 79 y 80 de la Ley de Procedimiento Administrativo (de 1958), imponen al órgano que conoce del procedimiento la obligación de notificar derechos e intereses, utilizando sistemas de comunicación que dejen constancia en el expediente de la recepción, de la fecha y de la identidad del acto notificado. Era pues, inexcusable, para que el recurrente hubiera podido realizar una completa defensa de sus derechos, que esos requisitos de comunicación en forma de las resoluciones sancionatorias, primero, y de los avisos de que la exacción pasaría a la vía de apremio, después, constarán en las actuaciones; circunstancia que no puede estimarse acreditada $[\ldots]$, al no estar apoyados por una justificación documental que demostrara, que la Administración sancionadora había dado cumplimiento a los requisitos impuestos por la Ley, para la notificación en forma de los actos y resoluciones, que, como el que imponía la multa, afectaban a los derechos del actor, y condicionaban la apertura del período de pago voluntario y ulterior prosecución de la vía de apremio».

Esta sentencia nos proporciona una clave para solucionar la cuestión que nos ocupa: si sanción administrativa se identifica con liquidación tributaria a

tencioso-Administrativo, Sección Tercera) de 31 de julio de 2002 -recurso 7207/1998- (JUR 2003, 21632); STSJ de Cataluña (Contencioso-Administrativo, Sección Primera) de 4 de abril de 2001 -recurso 2308/1997- (JUR 2001, 222428); STSJ de Murcia (Contencioso-Administrativo, Sección Segunda) de 10 de noviembre de 1999 -recurso 2365/1996- (RJCA 1999, 3812); STSJ del País Vasco (Contencioso-Administrativo, Sección Primera) de 12 de julio de 1999 -recurso 2533/1996- (RJCA 1999, 3013).

Identifican la falta de notificación de la sanción en materia de tráfico con la falta de liquidación tributaria en el procedimiento de ejecución mediante el establecimiento del apremio STSJ de Cataluña (Contencioso-Administrativo, Sección Cuarta) de 17 de diciembre de 2003 -recurso 2713/1998- (RJCA 2004, 102); STSJ del País Vasco (Contencioso-Administrativo, Sección Tercera) de 30 de marzo de 2000 -recurso 5216/1996- (RJCA 2000, 1781); STSJ de Cataluña (Contencioso-Administrativo, Sección Quinta) de 1 de diciembre de 1998 -recurso 1203/1998- (RJCA 1998, 4889) y STSJ de Galicia (Contencioso-Administrativo, Sección Tercera) de 19 de diciembre de 1996 -recurso 8439/1994- (RJCA 1996, 2283) y STSJ del Principado de Asturias (Contencioso-Administrativo) de 29 de septiembre de 2006 -recurso núm. 21/2002- (JUR 2006, 251394). 
los efectos de recaudación y, si ésta última debe notificarse expresamente con indicación de los plazos de cumplimiento de la obligación en periodo voluntario, se deduce que la Administración sancionadora debe hacer lo que se le exige a la Administración Tributaria en el caso de las liquidaciones, notificar expresamente la sanción con indicación de los periodos de cumplimiento mediante el ingreso voluntario. La Sala Tercera del Tribunal Supremo, en una línea jurisprudencial que se inicia con la STS $\left(3^{\underline{a}}, 2^{\underline{a}}\right)$ de 28 de octubre de 2005 -recurso de casación núm. 6297/2000- (RJ 2005, 7617) ${ }^{28}$ sitúa la cuestión en los siguientes términos: «Se trata, en definitiva, de determinar si la Administración puede acudir a la vía de apremio automáticamente tras la confirmación, en última instancia administrativa, de una liquidación cuya ejecutividad ha estado provisionalmente suspendida, y eso sin tener que realizar ninguna notificación al administrado, que se considera que debe pagar voluntariamente al recibir la notificación de la resolución que agota la vía administrativa confirmatoria de aquella liquidación (notificación que en este caso había sido recurrida en sede jurisdiccional).

Piénsese en que la Administración Tributaria de que se trate conoce cuando se le notifican a ella las resoluciones de los Tribunales económico-administrativos o las sentencias de los Tribunales de la Jurisdicción, pero no tiene por qué saber cuándo aquellas resoluciones o sentencias han sido notificadas al obligado al pago, por lo que no hay un término cierto con el que pueda operar para comenzar a computar el inicio del plazo de pago voluntario [...] En esa línea se manifestó esta Sala en su sentencia de 31 de mayo de 1993 -Rec. núm. 937/1989- (RJ 1993, 3649). Sin perjuicio de lo anterior, estimada la reclamación o recurso frente a una liquidación anulada cuya ejecución había sido suspendida, no puede producirse automáticamente el apremio sino que es necesario que el órgano de gestión notifique expresamente al interesado advirtiéndole que ha quedado sin efecto la suspensión y señalando plazo para el ingreso en período voluntario. En consecuencia, el órgano de gestión, una vez recibidas las actuaciones ejecutivas del órgano que hubiera resuelto el recurso, tendrá que dirigir necesariamente una notificación expresa al interesado en ejecución de lo resuelto, advirtiendo que ha quedado sin efecto la sus-

${ }^{28}$ Y se consolida con las SSTS $\left(3^{a}, 2^{2}\right)$ de 16 de marzo de 2006 -recurso de casación núm. 7705/2000- (RJ 2006, 1844) y de 27 de septiembre de 2006 -recuso de casación núm. 6782/2001(RJ 2006, 6480). Un comentario a la primera en CALVO VERGEZ, Juan: "La imposibilidad de iniciar un procedimiento de apremio sin haber notificado de manera expresa la suspensión de la ejecutividad de una liquidación tributaria impugnada y la apertura de plazo para proceder al pago voluntario: el razonable criterio de la STS de 28 de octubre de 2005 (RJ 2005, 7617)”. Jurisprudencia Tributaria Aranzadi núm. 12/2006. 
pensión, señalando plazo para el ingreso en período voluntario y apercibiendo del apremio y ejecución de la garantía si no se produce tal ingreso. De no cumplirse todos estos requisitos, el apremio será nulo, porque sin advertencia de que ha quedado sin efecto la suspensión, ni señalamiento de plazo para ingreso en plazo voluntario, se sitúa al contribuyente en total indefensión. Y es que al igual que ocurre en la ejecución de las sentencias dictadas por los Tribunales de este orden jurisdiccional Contencioso-Administrativo, en las que se necesita una resolución expresa de ejecución del fallo, también en la ejecución de los acuerdos de los órganos económico-administrativos se hace necesaria tal resolución, la cual ha de ser notificada al interesado, con constancia del plazo de ingreso en período voluntario.

La solución que aquí se adopta es la que, en el plano de la equidad, han venido aplicando los Tribunales de Justicia y es la que ha sido adoptada por el legislador en la reforma que el Real Decreto 448/1995, de 24 de marzo, ha introducido en el art. 20.8 del Reglamento General de Recaudación. Es, pues, obligado que el órgano de gestión conceda expresamente al interesado en estos casos un plazo para el ingreso de la deuda en período voluntario.

No consta que la Administración Tributaria hubiera dado cumplimiento en el caso de autos a su deber de acusar recibo de la resolución del TEAC y disponer su ejecución, dictando los correspondiente actos ejecutivos previstos en el art. 116 del Reglamento de 20 de agosto de 1981, cuyo apartado 4 se refiere a «la indispensable notificación de dichos actos de ejecución con instrucción de los recursos procedentes y en la cual, por elementales razones de justicia, ha de indicarse el plazo específico para solventar la deuda en período voluntario y, por tanto, sin recargo de apremio y sin ejecución del aval».

En definitiva, en la ejecución de las liquidaciones tributarias, entendiendo como tal a las sanciones administrativas susceptibles de ejecución mediante el establecimiento del procedimiento administrativo de apremio, se requiere un acto expreso, que en este caso sólo se obtiene por la resolución expresa del recurso de alzada confirmando total o parcialmente la sanción, que habrá de notificarse al interesado con la correspondiente información sobre el plazo de ingreso en periodo voluntario ${ }^{29}$. Resulta obvio que esta situación no se

29 Sobre la importancia de las notificaciones, se pronuncia el Consejo de Estado, en su Dictamen núm. 1403/2003, de 22 de mayo (HACIENDA), sobre el Anteproyecto de la Ley General Tributaria: "La regulación legal de esta materia ha de ponderar y sopesar de manera exquisita dos principios en cierto sentido contradictorios: de un lado, la garantía de que el obligado tributario 
produce en los casos de desestimación por silencio administrativo negativo del recurso de alzada interpuesto contra resoluciones sancionadoras, donde lo único que obtendrá el recurrente será una ficción jurídica y no la notificación de que su recurso ha sido desestimado, que la sanción ha adquirido firmeza y que para cumplirla: qué ingreso habrá de realizar, cómo, cuando y dónde debe hacerlo de modo voluntario para evitar la ejecución forzosa mediante el establecimiento de la vía de apremio.

Ya en una cuestión específica del procedimiento de apremio como son los motivos de oposición a la providencia de apremio, limitados a los previstos en el artículo 167 LGT, que la jurisprudencia ha considerado tasados y el Tribunal Constitucional compatible con las exigencias del derecho a la tutela judicial efectiva, pues: «la seguridad jurídica justifica que se rechace la posibilidad de debatir indefinidamente las discrepancias suscitadas entre los sujetos de la relación jurídico-tributaria y que iniciada la actividad de ejecución, en virtud de título adecuado, no puedan trasladarse a dicha fase las cuestiones que debieron solventarse en la fase declarativa, por lo que el sujeto pasivo de los impuestos no puede oponer a la providencia de apremio motivos de nulidad que afecten a la propia liquidación practicada» ${ }^{30}$, encontramos un punto de conexión entre sanción administrativa y liquidación tributaria en el motivo de oposición del artículo 167.3.c) LGT, falta de notificación de la liquidación

sea notificado de las resoluciones que le afectan sin que se produzca indefensión; de otro lado, el contrapeso de eficacia evitando todo aquello que impida a la Administración Tributaria cumplir con su misión, como consecuencia de actuaciones negligentes y aun dolosas de los obligados a frustrar la notificación y con ello la recaudación por la Administración de los tributos.

El anteproyecto debería recoger más explícitamente el principio de que los actos tributarios que deben ser inexcusablemente notificados a los obligados tributarios. Entre ellos, sin duda, nominatim las liquidaciones tributarias y las providencias de apremio.

La STSJ del Principado de Asturias (Contencioso-Administrativo) de 29 de septiembre de 2006 -recurso núm. 21/2002- (JUR 2006, 251394) anula una providencia de apremio por no haberse notificado la resolución expresa desestimatoria del recurso de alzada en una infracción de tráfico.

${ }^{30}$ STS $\left(3^{\mathrm{a}}, 2^{2}\right.$ ) de 22 de julio de 2005 -recurso de casación núm. 136/2000- (RJ 2005, 8839). Sobre el carácter tasado de los motivos de oposición a la providencia de apremio, véase el Informe de la Abogacía del Estado de 9 de junio de 1999 realizado por D. Jesús Besteiro Rivas, Abogado del Estado-Jefe en Segovia, sobre Tribunales Económico-Administrativos Regionales. Forma en que han de remitirse los expedientes administrativos por parte de las Jefaturas Provinciales de Tráfico a los Tribunales Económico-Administrativos. Extensión y límites de las facultades revisoras éstos últimos cuando resuelven reclamaciones referidas a la ejecución por la vía de apremio administrativo de sanciones pecuniarias en materia de tráfico y seguridad vial. 
practicada $^{31}$. Si en el ámbito del procedimiento de apremio se identifican sanción y liquidación, y la "pretendida" firmeza de la sanción que la convierte en ejecutiva (artículos 94 y 138.1 LRJPAC) deriva de la desestimación presunta por silencio del recurso de alzada interpuesto contra la misma -que corresponde a una conducta omisiva de la Administración sancionadora que incumple su obligación de resolver expresamente el recurso de alzada planteado-, es obvio que si no existe resolución expresa tampoco existirá notificación de una resolución que no se ha dictado, y tampoco de la liquidación, concepto con el que en el ámbito del procedimiento apremio se corresponde la resolución sancionadora que goza de ejecutividad. No obstante, la propia jurisprudencia, que ha considerado numerus clausus los motivos de oposición a la providencia de apremio establecidos hoy en el artículo 167 LGT, ha matizado este carácter tasado, afirmando: «Pero ello, claro está, resulta justificado sólo cuando se ha tenido oportunidad de oponer los motivos procedentes contra la liquidación, no en cambio cuando no ha existido tal posibilidad, como ocurre en el caso de la falta de notificación reglamentaria de la liquidación, que precisamente constituye uno de los motivos contemplados en el referido artículo 137 LGT/1963 -hoy artículo 167.3.c) LGT-. En definitiva, la falta de existencia de acto válido de gestión, consecuencia de una declaración judicial, puede hacerse valer frente a la providencia de apremio cuando no se ha tenido oportunidad de alegar tal motivo en la fase declarativa. Y esto es lo que parece haber ocurrido en el presente caso si nos atenemos al único expediente disponible del que no puede deducirse que se hubiera notificado la correspondiente liquidación ni que con posterioridad a la sentencia de esta Sala de 1 de octubre de 1984 la recurrente haya tenido otra ocasión distinta de la que le proporcionaba la providencia de apremio para alegar la incidencia y con-

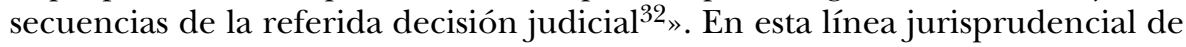

${ }^{31}$ El Informe de la Abogacía del Estado de 9 de junio de 1999 realizado por D. Jesús Besteiro Rivas, Abogado del Estado-Jefe en Segovia, sobre Tribunales Económico-Administrativos Regionales. Forma en que han de remitirse, op. cit., considera que el motivo de oposición "falta de notificación de la liquidación"parece que ha de entenderse referida exclusivamente a la sanción impuesta, pero no a cualesquiera otras notificaciones practicadas o intentadas en el seno del expediente sancionador (por ejemplo, del boletín de denuncia, o de la puesta de manifiesto del expediente, o de la propuesta de resolución).

${ }^{32}$ STS $\left(3^{a}, 2^{2}\right)$ de 22 de julio de 2005 -recurso de casación núm. 136/2000- (RJ 2005, 8839). También SSTS de 1 de junio de 1991 (RJ 1991, 4881), 24 febrero y 27 junio de 1995 (RJ 19951032 y RJ 1995 5261), 6 de febrero y 9 de diciembre de 1996 (RJ 1996, 1156 y RJ 1996, 9115) y 16 de septiembre de 1999 (RJ 1999, 6726). La STC 157/2007, de 2 de julio, anula una providencia de apremio por la que se pretendía ejecutar una sanción de tráfico al no haber sido notificados los actos del procedimiento administrativo sancionador al interesado, provocándole indefensión. 
exigir un título adecuado para la ejecución se alinea la STS (3 $\left.3^{\mathbf{a}}, 5^{\underline{a}}\right)$ de 17 de enero de 1996 -recurso de apelación núm. 3584/1991- (RJ 1996, 27), que aunque resuelve un caso concreto difícilmente repetible por su especificidad, como es el de una sanción urbanística recurrida en reposición, donde el recurso es resuelto por un órgano manifiestamente incompetente como es el instructor del procedimiento sancionador, impone un severo correctivo a la Administración, argumentando: " 1. a $)$ No se puede presumir, como hace la parte apelante, que el acto imponiendo la sanción sea válido, existiendo contra él un recurso de reposición, interpuesto en Correos en tiempo y forma, que es resuelto por el Instructor, que era manifiestamente incompetente para resolverlo (art. 47.1.1 de la LPA -hoy artículo 62.1.b LRJPAC). No se trata, en efecto, de que la mera interposición de un recurso de reposición destruya la presunción de validez del acto ni evite su ejecutividad, sino que el problema aquí radica en que el Ayuntamiento decidió la ejecución del acto matriz dando por buena una resolución del recurso de reposición que era nula de pleno derecho; éste es el fondo del dilema, y no, como expone la Corporación apelante, una mera cuestión de ejecutividad. 2.ạ) Lo dicho contesta también al segundo motivo, ya que no puede sostenerse que el acto que decide la ejecución de otro anterior sea absolutamente independiente de la resolución del recurso de reposición interpuesto contra el primero, porque, como decimos, el Ayuntamiento decidió la ejecución dando por buena la resolución del recurso de reposición, que era nula de pleno derecho".

Aunque esta situación, providencia de apremio derivada de sanción cuya "firmeza" deriva de la desestimación de un recurso de alzada por silencio, se enmarca en el motivo contemplado en el artículo 167.3.c) LGT, sería el supuesto más extremo al no existir sanción-liquidación que goce de ejecutividad, aunque el motivo se refiere a la falta de notificación de ésta, por lo que el mismo puede extenderse a otras conductas de la Administración "menos radicales" como sería la falta de notificación de la resolución expresa del recurso de alzada, puesto que el motivo se refiere a la notificación, que es requisito de eficacia y no de validez del acto, mientras que el supuesto que estudiamos se caracteriza por la inexistencia de un acto válido, que, precisamente porque no existe, no puede ser notificado.

Otro argumento favorable a esta postura lo encontramos en el artículo 172.3 LGT, que determina que la Administración tributaria no podrá proceder a la enajenación de los bienes y derechos embargados en el curso del procedimiento de apremio hasta que el acto de liquidación de la deuda tributaria ejecutada sea firme salvo en los supuestos expresamente autorizados por este precepto. La consideración de deuda de las cantidades que los obligados al pa- 
go por la imposición de la sanción deberán ingresar y la identificación de la sanción con la liquidación determinan que aunque se haya iniciado el procedimiento de apremio y la Administración haya dictado actos materiales de ejecución como son el embargo de bienes y derechos, la ley prohíbe a ésta la enajenación de éstos hasta la firmeza de la liquidación, esto es, de la sanción, que si es susceptible de ser recurrida en alzada, sólo se producirán con la notificación de la resolución expresa desestimando total o parcialmente el recurso administrativo interpuesto contra ésta.

\section{EPÍLOGO}

Las reflexiones precedentes conducen a la conclusión que la ejecutividad -que no debe confundirse con la realización por la Administración de actos materiales de ejecución- de un acto administrativo sancionador contra el que se ha recurrido en alzada sólo se alcanzará cuando el órgano superior jerárquico al que impuso la sanción, competente para resolver el recurso, cumpla con su obligación legal de resolver expresamente y notifique su decisión expresa al interesado, con indicación de cómo y en qué plazos debe cumplir la obligación económica derivada de la sanción en periodo voluntario. La desestimación por silencio de un recurso de alzada interpuesto contra una sanción no convierte a ésta en ejecutiva.

Una vez que la sanción sea ejecutiva por haber sido desestimado de manera expresa, total o parcialmente, el recurso de alzada y notificada la resolución al sancionado, ésta será ejecutable por la Administración que podrá proceder a su ejecución forzosa si un fuere cumplida de manera voluntaria por el sancionado. No obstante, la Administración, para garantizar el derecho a la tutela judicial efectiva del administrado, deberá demorar los trámites de ejecución hasta que un tribunal resuelva sobre la solicitud de suspensión de la ejecución de la sanción si ésta se hubiere solicitado por el sancionado.

La remisión expresa de la normativa reguladora de la ejecución administrativa mediante el procedimiento de apremio a la normativa tributaria determina que deban conjugarse conceptos que en principio no se corresponden como son sanción administrativa con liquidación tributaria. Identificados estos conceptos, la jurisprudencia exige para la ejecución de las sanciones por la vía ejecutiva los mismos requisitos que para el establecimiento del procedimiento de apremio para la exacción de liquidaciones tributarias. 


\section{ABREVIATURAS:}

ATC: $\quad$ Auto del Tribunal Constitucional.

CE: Constitución Española.

ATSJ: $\quad$ Auto del Tribunal Superior de Justicia.

JUR: $\quad$ Repertorio Aranzadi de Jurisprudencia y doctrina de tribunales.

LGT: $\quad$ Ley 58/2003, de 17 de diciembre, General Tributaria.

LJCA: Ley 29/1998, de 13 de julio, reguladora de la Jurisdicción Contencioso-Administrativa.

LOPJ: Ley Orgánica 6/1985, de 1 de julio, del Poder Judicial.

LPA/58: Ley de Procedimiento Administrativo de 17 de julio de 1958.

LRJPAC: Ley 30/1992, de 26 de noviembre, del Régimen Jurídico de las Administraciones Públicas y Procedimiento Administrativo Común.

RJ: $\quad$ Repertorio Aranzadi de Jurisprudencia del Tribunal Supremo.

RJCA: Repertorio Aranzadi Contencioso-Administrativo.

RGR: Reglamento General de Recaudación, aprobado por Real Decreto 939/2005, de 29 de julio.

SAN: $\quad$ Sentencia de la Audiencia Nacional.

STC: $\quad$ Sentencia del Tribunal Constitucional.

STJCE: Sentencia del Tribunal de Justicia de la Comunidades Europeas.

STS: $\quad$ Sentencia del Tribunal Supremo (cuando va seguida de dos números ordinales, el primero corresponde a la Sala y el segundo a la Sección).

STSJ: Sentencia del Tribunal Superior de Justicia. 